\title{
DECOLONIZING 'INTEGRATION': A POST-COLONIAL ANALYSIS OF IMMIGRANT 'INTEGRATION' IN CANADA \& GERMANY
}

By

Hasrat Grewal Gill, BA (Hons.), York University, 2014

\author{
A Major Research Paper \\ presented to Ryerson University
}

in partial fulfillment of the requirements for the degree of

\begin{abstract}
Master of Arts
in the Program of Immigration and Settlement Studies
\end{abstract}

Toronto, Ontario, Canada, 2019

(C) Hasrat Grewal Gill, 2019 


\section{AUTHOR'S DECLARATION FOR ELECTRONIC SUBMISSION OF A MAJOR RESEARCH PAPER (MRP)}

I hereby declare that I am the sole author of this Major Research Paper. This is a true copy of the MRP, including any required final revisions, as accepted by my examiners.I authorize Ryerson University to lend this MRP to other institutions or individuals for the purpose of scholarly research.

I further authorize Ryerson University to reproduce this MRP by photocopying or by other means, in total or in part, at the request of other institutions or individuals for the purpose of scholarly research.

I understand that my MRP may be made electronically available to the public. 


\title{
DECOLONIZING 'INTEGRATION': A POST-COLONIAL ANALYSIS OF IMMIGRANT 'INTEGRATION' IN CANADA \& GERMANY
}

\author{
Hasrat Grewal Gill \\ Masters of Arts 2019 \\ Immigration and Settlement Studies \\ Ryerson University
}

\begin{abstract}
Migrant 'host' countries in the global north demand that newcomers 'integrate' into their societies by demonstrating language skills, economic participation, socialization, and adjusting to the norms and values of the destination country. However the question that remains unanswered is: who is the 'host' population, and who creates the norms and values that the newcomers are required to match up to? In the context of immigrant integration, this paper applies a postcolonial lens to understand the historical linkages in Canada (settler society) and Germany (ethic nation) that shape the everyday realities of immigrants in the present. The concept of immigrant 'integration' can be seen as a form of present-day colonialism that works to re-impose the idea of European hegemony over 'other' racialized groups, and distracts from the recognition and redress of Indigenous and immigrant rights.
\end{abstract}

Key words: Canada, Germany, Integration, immigration, colonialism, racism, decolonization 


\section{ACKNOWLEDGEMENTS}

I acknowledge that I live, learn, breathe and partially wrote this Major Research Paper (MRP) on the unceded, ancestral, occupied and traditional lands of the 'Dish With One Spoon Territory' (Toronto, ON) and the 'Land of the Coast Salish peoples- Sk kxwxwú7mesh' (Squamish, $\mathrm{BC}$ ). While writing this MRP, I hold up the resistance of Indigenous peoples, the voices of the immigrants and refugees, their resilience and strength in the face of ongoing dispossession and colonial violence. I thank the faculty of Immigration and Settlement Studies (ISS) program at Ryerson University to reaffirm that any academic work around the issue of migration and settlement must be rooted in the acknowledgment of the true ancestors, the Indigenous peoples, who have cared for these lands since time immemorial and still do.

A big part of this MRP has been completed at the Institute for Migration Research and Intercultural Studies (IMIS), Osnabrück, Germany via an academic exchange program. I am grateful to the ISS program, IMIS, MITACS Globallink Research Grant program to make this a possibility. The experience and valuable interactions in Germany has played a major role in the development of this MRP.

First and foremost, I would like to express my deepest gratitude to my supervisor, Dr. Harald Bauder for sparking my interest in the topic, and encouraging me to think critically. You are a true inspiration and will never cease to amaze me with your dedication, hard work and efficiency. I'd like to sincerely thank my second reader, Dr. Sedef Arat-Koc for playing a key role in the process by providing valuable feedback and insightful comments. I am grateful to have two experts in the field to guide me through this process. This would have not been possible without you both!

The list of gratitude is long and still continues; I would like to thank Mama and Papa for always believing in me and supporting me at every step of my life. Thank you for making me what I am today, I can never pay back for your unconditional love! I would like to thank Neetu masi, Heeto Masarji, Parneet Veer, Chetan bhabhiji, Hazel, Rehat and Muraad for making my stay in Toronto so memorable with your endless love. I owe my gratitude to my grandmother, mummy, who continues to instill the awareness of society around me by sharing her lessons from her life-long readings; I thank her for accommodating with my hectic schedule for past few months and not being able to call her that often. I owe my gratitude to my maternal grandmother, 
nani, I always have been, and shall ever be in the awe of the immense strength you lived your life with. Additional gratitude to Anu chachaji for the thought provoking conversations and always being an inspiration for me.

Words fall short to thank you, my partner, dearest Gursimran. Thank you for being my best friend, my support and my motivator. When days seemed grey and I doubted if I could carry on, you gave me strength. Thank you for all you do for me, nothing would have been possible without you being on my side.

I would also take this opportunity to thank the wonderful cohort of 2018-19. It was an absolute pleasure to hear all these brilliant minds share their ideas in the classroom discussions. Additionally, I would like to thank many people that I've met over the years who have influenced me in numerous visible and invisible ways. I owe my gratitude to every ordinary person, who overcomes not-so-ordinary challenges on a daily basis. Those real unsung heroes never stop inspiring me!

Last but not the least, I dedicate this work to my grandfather, my dearest Daddy. I know you would be so proud. I shall see you again! 


\section{AUTHOR'S DECLARATION FOR ELECTRONIC SUBMISSION OF A MAJOR RESEARCH PAPER (MRP) ........................................................................................................ ii}

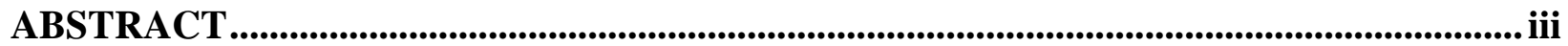

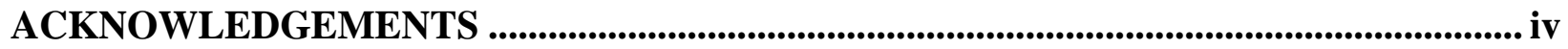

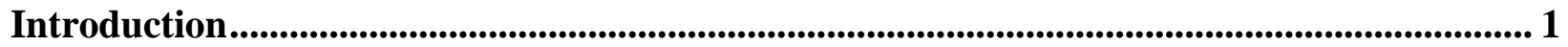

Chapter 1: Literature Review...................................................................................................... 4

a. Understanding Immigrant 'Integration' ................................................................................... 4

b. Decolonizing 'Integration' ........................................................................................................ 11

Chapter 2: Methodology and Approach ................................................................................ 14

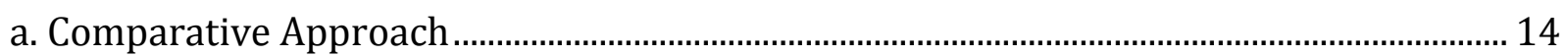

b. Integrative Literature Review ………………………………………………………….... 15

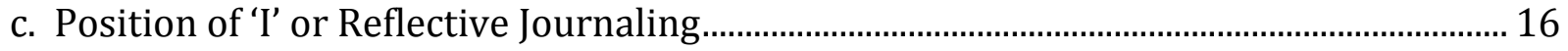

Chapter 3: Integration in Canadian Context ....................................................................................... 17

a. The Canadian 'Nation' and Colonialism................................................................................. 17

b. 'Canadian Settler Colonial Nation', Indigenous people and Immigrants.............................. 19

c. 'Multiculturalism', 'Integration' and Immigration................................................................... 22

i. Economic 'Integration' of Immigrants...................................................................... 25

ii. Social 'Integration' of Immigrants................................................................................ 28

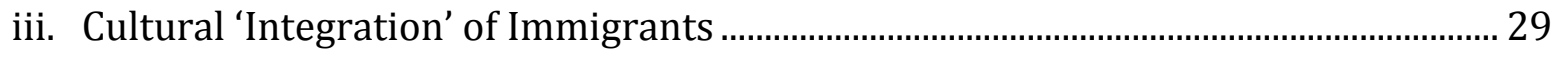

d. 'Multiculturalism', 'Integration' and Indigenous peoples ...................................................... 33

i. Economic 'Integration' of Indigenous peoples ................................................................. 35

ii. Social 'Integration' of Indigenous peoples........................................................................ 37

iii. Cultural 'Integration' of Indigenous peoples …………................................................... 39

Chapter 4: 'Integration' in German Context ................................................................................. 41

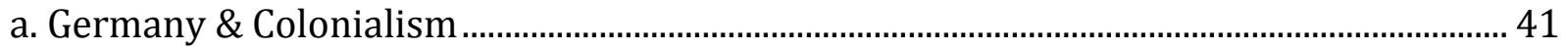

b. 'German Ethnic Nation' and Immigrants ............................................................................ 43

c. 'Multiculturalism', 'Integration' and Immigration.................................................................. 46

i. Economic 'Integration' of Immigrants............................................................................. 47

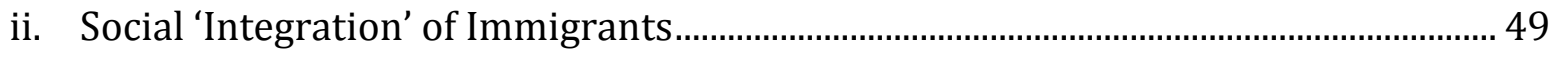

iii. Cultural 'Integration' of Immigrants ………………………………………………... 51

Chapter 5: Conclusion and Discussion .......................................................................................... 55

References............................................................................................................................................5 59 


\section{Introduction}

During a panel discussion at the 2016 Global progress conference, Canadian Prime Minister, Justin Trudeau commented that the discrimination against the immigrants is 'nothing new' in Canada. He added:

There are districts (in Montreal) where Italian grandmothers still pretty much only speak Italian and don't speak that much French or English. But their kids and grandkids are seamlessly and completely integrated into Montreal and the only difference is they tend to be trilingual and not just bilingual.... The first generation is always going to have challenges in integrating... This country didn't happen by accident... And it won't continue without effort. When we think about integration and success we can't be overly impatient. The question is, do you engage or participate or say 'I'm not going to talk to you until you hit the norm or the perfect ideal that we all aspire to', I think (the latter) is wrong (CBC 2016).

Upon these comments, London UK Mayor Sadiq Khan praised Prime minister Trudeau for his 'progressive' politics and noted that Canada "has become a beacon of how a civilized G7 country should treat those who are vulnerable and need help" (CBC 2016). This idea of 'inclusion' and 'being patient' with the population that 'needs help' might have been well received by a lot of newcomers, however, it raised many questions about immigrant 'integration' in my mind which I hope to also address in the MRP.

I remember feeling a little uncomfortable about PM Trudeau's comments and discussed it with my friend: "But, aren't we all suppose to follow the host country? After all they let us in, we are on their land, and we should be grateful" said my friend. I was hesitant to agree with her at the time. However, this conversation forced to me to think how I felt when I came to Canada, from one colonized nation to 'other', once again as an 'other'. Before proceeding further, I wish 
to clarify the socio-political location from which I author this piece. I solemnly declare that I author this piece as an 'other'. I was born and raised in the north western region of India. Being a minority in the Hindu nation comes with its own challenges on a personal and collective level. The lives of minorities are always surrounded by various visible and invisible societal and political pressures to 'integrate'. Therefore I remain an 'other' in my 'home' and the 'host' country. Like many other 'others' I continuously struggle to think if I should 'integrate' or not? Or if I really have a choice?

But the foremost question is: what is 'integration'? How do I become 'integrated'? May be I should colour my hair blond, then I'll probably be more 'integrated'? or maybe if I throw away my hijab or duppata and do the 'right' makeup to look as light as possible. Or maybe if I meet the 'right' people at the 'right' places, it might make me look 'integrated', right? Or maybe if I should just speak 'their' language all the time, even at home. But then what about my Indian accent? I have heard there are some classes that help you to change your accent, may be that can make me more 'integrated'? How far do I have to come from my identity to be 'enough'? Where do I stop? But will I ever be 'enough'? May be not ... but to be a good citizen, I have to keep learning and keep trying. May be if not me, my children will be 'enough'. But will they really be???

Under the current discourse of immigrant 'integration', these thoughts knowingly or unknowing cross the minds of newcomers, and I would be lying if I said that they didn't cross mine. Immigrating to a new country comes with its own challenges and pressures for the newcomers to perform well and succeed in the new country economically and socially. Therefore a newcomer starts feeling that 'integration' into the new country is inevitable and something that 
has to be done in order to succeed in the new home. However it is important to ask what does it really mean to 'integrate'? Who defines 'integration'? What are we 'integrating into'? Who measures 'integration'? How are these measurements put into place? And how are they carried forward? In the context of immigrant integration, this paper applies a postcolonial lens to understand the historical linkages in Canada (settler society) and Germany (ethic nation) that shape the everyday realities of immigrants in the present. In this MRP, I argue that the concept of immigrant 'integration' can be seen as a form of present-day colonialism that works to re-impose the idea of European hegemony over 'other' racialized groups, and distracts from the recognition and redress of Indigenous and immigrant rights. I aim to answer the following questions in the paper:

1) How do we define and appraise the 'integration' of newcomers in Canada and Germany?

2) How do the colonial continuities, settler histories, geographies and ethnicities shape the ‘integration' policies and practices in Canada and Germany?

3) How do the social, political, and structural factors in 'host' countries affect the 'integration' of immigrants? 


\section{Chapter 1: Literature Review}

\section{a. Understanding Immigrant 'Integration'}

The word 'integration', takes its origin from Latin word 'integer', which means an 'unscathed whole', therefore 'integration' has a reference to a 'social whole'. Historically the concept of 'integration' has developed from a traditional understanding in which "social was conceived as an integrated body" (Schinkel, 2018, p. 6). Frideres (2008) argues that the term 'integration' refers to "a society which is closely and intensely linked to its constituent parts, both groups and individuals" (Biles et al., 2008, p. 78). Therefore 'social cohesion' is one of the main characteristics of an 'integrated' society where various groups and members can display varying degree of ‘integration' (Entzinger \& Biezeveld, 2003 as cited in Biles et al., 2008, p. 79). Favell (2001) notes that 'integration' is “a vague concept that suggests a comforting view of modern society, heading in a teleological direction"; hence, the opposite of this implies 'disintegration' or dysfunction that leads to social breakdown (as cited in Biles et al., 2008, p. 78). Robinson (1998) suggests that "integration is a chaotic concept; a word used by many but understood differently by most" therefore the "concept is individualized, contested and contextual" (as cited in Ager \& Strang, 2008, p. 167). Despite the controversial nature of the concept, 'integration' remains of great significance to state policies across the world (Ager \& Strang, 2008). The 'integration' of newcomers is not just a responsibility of one tier of the government, but is instead a societal endeavour; 'integration' is defined as a "two-way street, where both immigrants and current citizens are expected to adapt to each other, to ensure positive outcomes for everyone in the social, cultural, economic, and political spheres" (Biles et al., 2008, p. 4). 
Similarly, Phalet \& Swyngedouw (2003) claims that "integration is best conceived as multidimentional- social, cultural, political, identity, and economic" meaning that due to its nature some immigrants might be considered 'integrated' in some dimensions, but excluded in others (as cited in Biles et al., 2008, p. 79). In the context of Canada, Dorais (2002) defines 'integration' as a “ two way process of accommodation between immigrants and native born Canadians" suggesting that there are mutual interactions between immigrant's treatment and adaptation (as cited in Biles et al., 2008, p. 79). Immigrant 'integration' is often measured by evaluating the 'degree' of state institutionalized assimilation pressures put on immigrant groups "to conform to Canadian norms- the very opposite of what multiculturalism is supposed to do" (Li 2003; Levitt 2004; Favell 2001as cited in Biles et al., 2008, p. 81). The service providers and policy makers define 'integration' as "adding single elements to an existing structure" and “joining these to an interconnected whole"; this kind of 'integration' means adding new and different populations to the existing social structures and ensuring the quality of connectedness between the two (Biles et al., 2008, p. 81). Levitt (2004) argues that research on "immigration and integration equates society with the boundaries of a particular nation-state" where the identities of the nation state become a norm which the immigrants have to conform to (as cited in Biles et al., 2008, p.85).

Benedict Anderson argues "the nations are communities of imagination" and that nationhood and nationalism are historically produced 'cultural artefacts' (Anderson 1991 as cited in Bauder, 2011, p. 7). Similarly other scholars argue that "nations are historically, geographically, socially, politically, and culturally grounded constructions" (Hobsbawn,1989; Gellner, 1983 as cited in Bauder, 2011, p. 7). From an understanding that "the nations are not 
pre-existing entities", Benedict Anderson (1991) notes that "the nation 'is imagined because the members of even the smallest nation will never know most of their fellow-members, meet them, or even hear of them, yet in the minds of each lives the image of their communion" (As cited in Bauder, 2011, p. 8). The historical perspective on national imagination becomes an important feature in defining what the nation looks like and what are its contents. Thus, "immigration remains an important aspect of the national imagination" (Bauder, 2011, p. 9). The debates around immigration policies reveal how the nation is imagined, who is imagined to belong, and who remains excluded from the national imagination (Bauder, 2011, p. 9).

We cannot deny the fact that the 'societies' we live in have histories; histories that are power driven, and histories that will make new histories. Schinkel (2018) claims that “today's (post) colonial divisions are the very effects of these 'societies' being on the move, enacting violent histories of continuing movement and influence - histories that expose the entire idea of 'people with a migration background' as the governing fictions they are” (p. 9). Bhambra (2017) states "the racialized histories of colonialism and enslavement continue to configure our present; it is only through an appropriate acknowledgement of the imperial and colonial histories that shape most current western national politics that we will be able adequately to reckon with the long-standing injustices that increasingly bear down upon us" (Bhambra, 2017, p. 227). Therefore suggesting that the practice of 'immigrant integration' and policy ideologies is a consequence of that history and knowledge production and can be seen as 'methodological whiteness' (Bhambra, 2017 p. 227).

Freeman (2004) argues that the concept of 'integration' is partly planned and partly accidental; "based on multifaceted, loosely connected set of regulatory rules, policies, 
institutions and practices in various spheres of society" that together make the framework in which immigrants and native born population lives (as cited in Biles et al., 2008, p. 87). The benchmarks of 'immigrant integration' are everywhere, yet not explicitly visible, that is why the measurements are never questioned, thought to be constant and left unaltered (Schinkel, 2018, p. 8). The immigrant 'integration' indicators, rules and practices are based on orientalist understanding of the 'norm' and the 'other'. 'Orientalism is sometimes taken to be simply a way of defining and 'locating' Europe's others” therefore the examination of Oriental languages, histories and cultures was done in a context where the supremacy of European civilization was unquestioned (Ashcroft \& Ahluwalia, 1999, p. 5). Therefore the 'Orientalist analysis' became the universal confirmation, "a coherent and strongly bounded area of social knowledge", "a system of statements by which the world could be known", in other words as Michael Foucault calls a “discourse" (Ashcroft \& Ahluwalia, 1999, p. 7). Ashcroft \& Ahluwalia (1999) argues that " there are certain unwritten and unconscious rules that define what can and cannot be said within a discourse, and the discourse of Orientalism had many such rules that operated within the area of convention, habit, expectation, and assumption" (p. 8). Foucault's notion of discourse is "a firmly bounded area of social knowledge" through which individuals understand themselves, their relationship to each other and their place in the world (Ashcroft \& Ahluwalia, 1999, p. 8). Similarly a colonial discourse is thus a system of statements and social knowledge about colonies and colonized people, about the colonizing powers and the relationship between the two (Ashcroft \& Ahluwalia, 1999, p. 9). Said argues that such discourses and texts "can create not only knowledge, but also the very reality they appear to describe" (Said, 1978 , p. 10). The western society takes the position of societal judge accessing the degree to which an individual is 
'modern' over 'traditional', 'normal' over 'pathological', and 'civilized' over 'degenerate'.

(Foucalt, 1999; Schinkel, 2018). Schinkel (2018) claims that with the colonial understanding of the 'western' society, 'integration' remains a neo-colonial practice. He argues that:

'Society' has always already 'started' the moment a dispensation of integration is granted to white citizens. And there is no socio-economic status high enough, no cultural assimilation perfect enough, that members of 'ethnic groups' can achieve, that qualifies them or their 'group' as unproblematically part of 'society'. They are still in the category of those who need to be monitored, as if they constitute a disease temporarily in retreat, which may resurface at any point - because that is how deep 'cultural incompatibilities' go" (Schinkel, 2018, p. 7).

Historically the European colonizers practiced both the 'assimilation' techniques and at the same time highlighted the differences between the 'us' and 'them' in the colonial contexts. "The colonial situation of moral monitoring is a key moment in genealogy of the study of immigrant integration" (Schinkel, 2018, p. 10). Looking back into the recent history, migration to Europe was only feasible for a very short period after the end of formal colonialism. The immigration policies were highly selective and restrictive for formerly colonized people. For the people who were coming, very formalized system of monitoring and record keeping was put into place (Hondius, 2011 as cited in Schinkel, 2018, p. 12). The tenacious survival of colonial effects and divisions is what Ann Stoler (2016) calls 'colonial duress'. The divisions and effects still exist in forms of power asymmetries that in turn shape raced classifications and ethnic taxonomies of researchers (as cited in Schinkel, 2018, p. 12). In relation to this, Gloria Wekker (2016) coins a term 'white innocence' which reveals a prevailing attitude among white researchers "that their whiteness should not and does not matter in this research" (as cited in Schinkel, 2018, p. 12). The overwhelming 'whiteness' in the research prioritizes the 'sameness' 
and excludes the 'otherness' within academia and governmental research institutions (Schinkel, 2018). Therefore, whiteness becomes more than just merely a 'skin colour' and reproduces a system of dominance. These perceptions have trickling-down effects on the political actions by reaffirming.

Schinkel (2018) argues that "what we have end up is a concept, and a practice, that is thoroughly purified both from notions of class and race" therefore separating those who are considered to make up 'society' and those who do not fit in and required to 'integrate' the society (p.4). Both in Canada and Germany, 'whiteness' claims neutrality, and non-racial universality and hence is seen as a benchmark to analyze the level of integration of newcomers. This discourse shifts the research focus of integration only on main 'problematic groups', therefore making the members of racialized groups a topic of research and scrutiny. It is evident that reciprocal nature of 'integration' has been rarely a subject of research; for instance there seems to be very minimal research on extent to which Canadian or German society and their institutions have changed as a result of diversity (Biles et al., 2008, p. 88). Therefore, it is crucial to understand here that present day integration markers can be seen as neo-colonial way of defining the 'other'.

Schinkel (2018) suggests that there are several problems with part/whole conception of integration: in a setting where societies are seen as a 'whole' and members as 'parts', the responsibility of integration gets individualized on the 'parts'. Therefore suggesting that the individuals such as migrants and their children bear the individual responsibility, thus "changing 'integration' from a system state to a state of being of an individual” (Schinkel 2018, p. 5). In the era of neo-liberalization of migration and integration policies, 'integration' becomes an 
individual responsibility, where the migrant is responsible for both, integration and disintegration (Van Houdt, Suvarierol \& Schinkel, 2011). The individual members who seem to 'misfit' in the social whole are believed to be single handedly responsible for being 'disintegrated' or 'not willing to integrate', consequently resulting in pitting 'society' against individuals who are different or problematic. (Schinkel, 2018). Furthermore, at the same time the individual responsibility of integration and disintegration extends to all the other members of the racialized or ethnic groups, which is later used to classify and monitor them (Schinkel, 2018).

The pitfalls of immigrant integration can be understood in two ways: one as a political way to describe the process in which migrants settle, second as a social science concept to analyze migration and settlement processes. The general social conceptual analysis of immigrant integration plays a very crucial role in problematization of migrant 'others' by creating a 'factual architecture' where such problemtizations take place, therefore itself becoming a part and parcel of the problem (Schinkel, 2018). Schinkel (2018) calls the entire set of assumptions, conceptions around the measurement of immigrant integration as a "mess of measurement" that operates as a machine for the production of hierarchized differences (p. 4). The construction of the 'Other' creates a power imbalance, which then exists through the characteristics of imperialism- brute political, economic, cultural and military rationales (Ashcroft \& Ahluwalia, 1999). Such conceptual base signifies that these are not problems of our preconceived society, whereas these are problems of individuals or groups who are from 'outside society' and need to be 'integrated'. Society is imagined as a pristine and pure domain that exists without any problems, therefore 'bringing people into the society' and their 'unwillingness to integrate' becomes the problem (Boersma \& Schinkel, 2018). Looking through an anti-racist perspective, "the lens of integration 
is believed to put the problem wrongly, leading to the distortion of the reality", nor the immigrants or their inability to integrate is the problem; the problem actually lies in the discourse of 'whiteness' that creates racial exclusions and inequalities (Saharso, 2019, p. 2). The immigrants are required to integrate in an imagined nation state, which is an inescapable outcome of pre-existing and pre-conceived historical notions of nationhood (Saharso, 2019, p. 2) The two case examples of Canada and Germany illustrate how contradictory the relationship between migration and territorial belonging is: migration discourses in both countries "have failed to legitimate the simultaneous inclusion of some 'migrants' (i.e. settlers) and some non'migrants' (i.e. residents born on the national territory), and the exclusion of some 'migrants' (i.e. people deemed unworthy of national membership) and some non- 'migrants' (i.e. Indigenous peoples) from the national imagination" (Bauder, 2018, p. 58).

\section{b. Decolonizing 'Integration'}

"Decolonization is as much a process as a goal"; a process that involves constructing and deconstructing, learning and unlearning, imagining and generating alternative institutions and relations (Walia, 2013, p. 250). It is a dual form of resistance that is responsive to dismantling current systems of colonial empire and systematic hierarchies, while also prefiguring societies based on equity, mutual aid, and self-determination. To understand decolonization, it has to be seen as a multilayered process; (de)colonization does not only deconstruct colonialism, but also deconstruct capitalism, racism, patriarchy, oppression, supremacy, social movements and relations. Activist Zainab Amadahy describes decolonization through a relationship framework, where no communities see themselves as superior, but rather share the roles and responsibilities in a collective setting towards each other (Walia, 2013). Hayden King states that the fundamental 
goal of decolonization is for the settlers, white and racialized people to get rid of the mindset that 'others' the Indigenous peoples (Stanley et al., 2014). Similarly, Taiaiake Alfred (2010) clarifies the goals of decolonization further by explaining that:

In order to decolonize, Canadians and Americans have to sever their emotional attachment to their countries and reimagine themselves, not as citizens with the privileges conferred by being a descendent of colonizers or newcomers from other parts of the world benefitting from White imperialism, but as human beings in equal and respectful relation to other human beings and the natural environment (p. 4).

Civil rights activist and writer, Audre Lorde writes "There is no such thing as a singleissue struggle because we do not live single-issue lives". Therefore coming from this approach, we must understand that decolonizing 'integration' cannot happen in a vacuum. Decolonizing 'Integration' starts with deconstructing the word 'integration' and asking questions on what it really means to 'integrate' or 'disintegrate'? As immigrants what are we required 'integrate' into? How and who has the power to define what 'integration' is? Decolonizing 'integration' is a multi step process, which involves challenging the Eurocentric systems of knowing; critically analysing the present system of migration research; challenging the neo colonial continuities that shape the present day norms; challenge the exclusionary nature of immigration and integration policies, and therefore redefining what it means to 'integrate'.

In both Canada and Germany, the systems of knowing, popular beliefs, and norms are embedded in the Eurocentric way. Referring to the field of migration research, the hegemonic or dominant discourses and subjugated or illegitimate discourses are produced by processes such as the sanctioning, including, excluding, valuing, and devaluing of certain concepts, ideas, language, words and people of different origins. Krysa et al. (2019) argues that it is essential to create awareness around the prevalence of colonial binaries in our way of producing knowledge 
so that we can challenge our assumptions on an individual and societal level. Research on migration and integration still very much remains in the hands of the Global North. Decolonial research breaches hegemonic western-centric imbalances, by questioning the premises behind established theories. In bringing decolonizing discussions to the field of migration research, we must first understand how the field has been impacted by colonization, so that we can go about dismantling and reversing those impacts, trends, and trajectories (Coulthard, 2014). It is essential to develop a counter-hegemonic approach that should be a source of inspiration for emerging scholars researching on the issues of migration and settlement. The insights gleaned from these discussions can enhance the relationships between 'western' communities and newcomers. 


\section{Chapter 2: Methodology and Approach}

\section{a. Comparative Approach}

For Alba and Foner (2014), examining migration through this comparative lens helps to "shed light on the 'invisible' - the systemic features of each society that, because they are national 'constants,' are often overlooked or taken for granted in a single country analysis" (p. 266). Shields et al. (2014) notes that because Canadian immigration and settlement policies are often celebrated as best practice, we have failed to consider "innovative policies from elsewhere," and that comparative studies help to "illuminate larger structural, political and other factors" that shape our outlook in this sphere (p. 24).

Bauder (2011) mentions that Canada and Germany are rarely seen as two countries of comparison in the field of migration research, however, both the countries make exceptional case studies because of their "different historical attitudes towards migration" but "same political ideological configuration that could be described as the "West"' (p. 4). The comparisons of Germany and Canada in migration research and policy "can de-center what is taken for granted" and thereby "challenge conventional wisdom" related to immigration and integration (Bloemraad 2013 as cited in Bauder et al., 2014). "The value of this comparative approach lies in juxtaposing important differences and highlighting similarities between two countries that have been situated rather differently in terms of their history and geography, but which have also been part of interconnected global economic, political and migration systems" (Bauder et al., 2014). With these methodological considerations in mind, this MRP will review relevant, recent Englishlanguage literature including journal articles, books, government documents, and gray scholarship. Methods of information retrieval include Ryerson University Library and Archives, 
Google Scholar and the Institute for Migration and Intercultural Studies Library at the University of Osnabrück. Key search terms include "migration"/ "settlement" / "integration" / "colonialism"/ "settler colonialism" / "Indigenous in Canada", and "migration" / "settlement" / "integration" / "colonialism" / "immigrants in Germany"

\section{b. Integrative Literature Review}

According to Nueman (2006), the integrative literature review is an essential academic aid in "presenting and summarizing the current state of knowledge on a topic", distilling central themes and frameworks, highlighting points of contestation and identifying avenues for further research (p. 112). The MRP will follow a counter hegemonic position in research and understand that my research may not be able to answer all the questions. "Some discourses are more powerful than others...Critical researchers tend to align themselves with a political agenda that is committed to challenging the relative power bases of competing discourses" (Locke, 2004, p. 37). Lather (1986) calls this 'research as praxis', an emancipator social science that is intended to redress structural inequalities and challenge the claim that research can and should be value neutral (Strega et al., 2005, p. 262). Neuman and Krueger argue that "critical social scientists critique existing social relations in order to transform them. The agenda of critical social science is to uncover myths, reveal hidden truths, and help people change the world for themselves" (Strega et al., 2005, p. 261).

"Research can be a powerful tool for social change. It also can, and has been, just as powerful in maintaining the status quo and supporting the evolution of societies that reward some people and inhibit others" (Strega et al., 2005, p. 260). However, I write this MRP in hope to ask questions, challenge existing norms, and build future relations. Therefore I foresee this 
MRP as 'research as resistance' and a valuable addition to social justice struggles, and solidarity initiatives in Canada and across the world.

\section{c. Position of 'I' or Reflective Journaling}

As a racialized immigrant woman, the position of ' $\mathrm{I}$ ' is very crucial in writing this research paper. Strega et al (2005) argues while working in an anti oppressive research framework it is essential to see ones position as potentially both as an oppressor and oppressed. In other words it means recognizing our own privilege and working to dismantle the unjust systems that keep us in that privileged space. My position as an immigrant with all settler privileges makes me no less, but an oppressor on the stolen lands. However, at the same time the interlocking structures of race, gender, colonialism, and migrant histories put me in the position of the oppressed.

The self-reflexive personal narratives provides researchers with different perspectives and knowledge towards "a multiplicity of positions in fields that up to now have been governed by a singular, exclusive, and privileged access to true representations and valid methods of knowing reality" (Lincoln, 1997, Grosz, 1993, as cited in Strega et al. 2005). Therefore, the position of 'I' will be useful in addressing the experiences of immigrants, and complexities of their positions in a settler nation. I am a strong believer that our personal life experiences, social reflections, and informal conversations with friends and strangers are of essential value even in academic research. 


\section{Chapter 3: Integration in Canadian Context}

\section{a. The Canadian 'Nation' and Colonialism}

Thobani (2007) claims, "there prevails in Canada a master narrative of the nation", which is central to the law abiding character of its citizens who are responsible, compassionate, caring, and committed to the values of multiculturalism and diversity (p. 2). The narratives of Canadian nationhood resonates a discourse of a nation arising from common bonds of shared history, values, characteristics and aspirations; often popularized as "new people building a new land" (Thobani, 2007, p. 22). Similarly, Bauder (2011) uses the Hegelian dialectic of Self and the other to explore the narratives of Canadian nationhood. In the book Phenomenology of Spirit, Hegel argues that "a dialectical relationship exists between two subject positions: inward-focused selfreflection and outward searching observation of material circumstances", therefore "the contradictions between these two subject positions drive a dialectical movement of selfdiscovery and identity formation" (Hegel, 2005 [1807] as cited in Bauder, 2011, p. 17). By referring to the discursive process of negation and sublation, Bauder (2011) explains how the epistemological distinctions between the 'us' and 'them', the 'orient' and 'occident' are created; and then included in a way that immigrants are conceived as 'both other and not other' (Dauvergne, 2005 as cited in Bauder, 2011, p. 27).

In the foundational moment of Canadian nationhood the English and French became the two founding nations of Canada; whereas the Indigenous peoples and non-european immigrants were considered as enemy outsiders or 'others' (Thobani, 2007, p. 4). Although Indigenous people played a considerable role in establishing European settlers and had lived here centuries before the arrival of European settlers, they have remained marginalized in the national 
imagination. Instead, Canada was imagined as a society of European settlement, therefore suggesting that the formation of national identity in Canada established itself on the "practices of exclusion and inclusion" (Bauder, 2011, p. 9). In this national imaginary, the citizens of the nation face numerous challenges from the 'others'. On one hand, the Indigenous people are presented "as making impossible and unending demands for special treatment in their claims to lands and state funds and to hunting, fishing, and logging the nation's fast depleting resources" (Thobani, 2007, p.4). On the other hand, the immigrants are held responsible for " importing 'their' backward cultural practices into the country (dowry, honour killings), along with their diseases (West Nile Virus, Asian Bird Flu, Ebola), their ancient murderous hatreds (the Sikh/Indian, Tamil/Sinhalese conflicts, among others), and their criminal gangs (Colombian drug dealers, Chinese 'snakeheads,' Indo-Canadian gangs)” (Thobani, 2007, p. 4).

The process of 'exaltation' legitimizes the superiority of the Canadian national subjects, conceals the colonial violence towards the Indigenous peoples, and normalizes the 'othering' of non-european immigrants (Thobani, 2007). Therefore, "the racial configurations of subject formation within settler societies are triangulated: the national remains at the centre of the state's (stated) commitment to enhance national well being; the immigrant receives a tenuous and conditional inclusion; and the Aboriginal continues to be marked for loss of sovereignty" (Thobani, p. 18). In the Canadian context, the contemporary encounters between national subjects and Indigenous peoples "recap and reopen their past encounters of colonization, genocide, and dispossession, instantiating the past as living present". Likewise in the case of the immigrants, the contemporary encounters "reopen older histories of preferred and non-preferred races, of the internments and racial hatreds expressed in the projects to build Canada as a "white 
man's country"' (Thobani, p.22). Legal scholar Catherine Dauvergne observes that "national identity is the most powerful variable for giving an account of [immigration] law's features, changes, and applications' (Dauvergne, 2005: 26 as cited in Bauder, 2011, p. 6). Furthermore, Bauder (2011) adds that the relationship between the national identity and immigration is "neither one-dimentional nor linear" suggesting that they both are influenced and affected by each other (p. 7). Therefore, exaltation in a settler society can be seen as a technique of power that still remains an ongoing process through the legitimization of popular practices and neocolonial state policies. The governance has been possible by producing "certain subjects as exalted (nationals)", others marked for "physical and cultural extinction or utter marginalization (Indians)", and yet others for "perpetual estrangement or conditional inclusion as supplicants (immigrants, migrants, and refugees)" (Thobani, 2007, p. 9).

\section{b.'Canadian Settler Colonial Nation', Indigenous people and Immigrants}

In the settler Canadian nation, the geographies of immigration and settlement and colonial domination overlaps (Stanley et al., 2014, n.p). In the settler colony-cum-liberal democracy, the status of the immigrants remains ambivalent, fraught within the dynamics of the structural forces that propel their migration and their subsequent relocation between Indigenous peoples and nationals. Thobani (2007) claims that immigrants hold a very complex and ambiguous figure in the settler societies; "propelled into the circuit of migration by structural conditions within the global economy, as well as their desires for economic advancement, migrants have been party to the ongoing colonization of Aboriginal peoples" (p. 16).

Bauder (2011) argues that despite various historical, ideological and material connections, there is a systematic separation between the immigrants and Indigenous discourses 
in Canada. The settler society defines Canada's national identity politically by immigration, and not ethnically; therefore recognizing the presence of Indigenous peoples "would wreck havoc on the national identity of an immigration country" (Bauder, 2011, p. 517). Moreover, the denial of politics of territorial belonging and separation of Indigenous sovereignty and migration issues is productive; and is "constitutive of state, of national identity, citizenship, and the narratives and categories that animate them" (Coulthard, 2007; Egan, 2011 as cited in Stanley et al., 2014, n.p).

This "parallax gap obscures the material relationship between migration, settlement, and the displacement and subordination of Indigenous peoples" (Bauder, 2014, p. 20). The past and current experiences of Indigenous communities and racialized communities may be very distinct, but also overlap in various ways. Mama (1997) calls for recognition of 'pernicious continuities' between colonial, nationalist, and post-colonial systems. These pernicious continuities unravel the vicious and insidious continuities from colonial to post colonial, past to present; and help us to understand the ideological, temporal and spatial linkages, overlaps and continuities of over 500 years of colonialism and white supremacy globally (Upadhyay, 2013). Upadhyay (2013) argues that slavery of people of colour, and displacement and genocide of Indigenous communities are the two main defining features of colonial modernity, white supremacy and racism today. Smith (2006) elaborates further on these entangled histories, racial hierarchies and complicities, by theorizing white supremacy and its three pillars, namely: slavery/capitalism, genocide/colonialism and orientalism/war. The first pillar enables anti-black racism within communities of colour and provides opportunities or non-black communities to escape capitalist commodification of their bodies and labour. The second logic seeks to erase Indigenous peoples in order to enable the settlers to claim to their lands. And, third, the logic of Orientalism marks 
certain peoples or nations as inferior and deems them to be a constant threat to the empire (Upadhyay, 2013).

Stanley et al. (2014) added that there is nothing 'natural' about the separation of Indigenous and immigrant issues, whereas "they are being actively driven apart, and the resulting separation is constitutive of the racialized colonialist Canadian state" (n.p.). The diaspora and Indigenous communities have very closely related cultural formations, having in common the experience of displacements from a homeland and marginalization in the metropolitan settler state, but the differences in their histories of displacement have created different political trajectories that distance the two from each other (Coleman, 2016, as cited in Chatterjee, 2018). This de-linking of immigrant exploitation and Indigenous land dispossession has contributed to the mystification of settler political economy that thrives on the separation of both political subjects and projects (Chatterjee, 2018). Racial logics of the state erase the relationships and linkages between racialized communities and Indigenous communities. It creates isolated binary relations between the state (white settler society) and Indigenous communities and between the state and the other racialized communities (Upadhyay, 2013).

Chatterjee (2018) emphasizes that the contemporary settler colonialism should be critically understood as an interlinked structure of immigration, labour exploitation, and Indigenous dispossession. However it is important to understand that in many ways, the racialized vulnerability and disposability of immigrants make them support settler colonial projects. Migration historian, Laurie Bertman writes: "The very process of becoming a good, successful, moral, and respectable citizen with access to the resources of the state transforms newcomers into colonialists" (Stanley et al., 2014 as cited in Chatterjee, 2018). Therefore, 
unconsciously the immigrants might just follow the socio-legal legitimization of dominant white structures and fail to recognize the importance of their participation in decolonization projects. Ahluwalia (2004) identifies this process of naturalizing the European thoughts, languages, knowledge systems, and epistemologies as 'cognitive imperialism'. Many newcomers come from histories of colonial conquests in their homelands and are therefore more vulnerable to accept the Eurocentric imperialist ideologies in their new homes (Ahluwalia, 2004 as cited in Khan et al., 2015, p. 149).

Settler colonialism remains a reality today, and is as much in the present as in the past. Upadhyay (2013) argues that not everyone is a settler on these stolen lands, 'settler' privileges and complicities vary depending on interlocking structures of race, class, gender, age, ability, nationality, sexuality and migrant histories. It is important to understand that the process of migration and colonialism is not the same; and many settlers themselves are a target of forced migration and racist neo-colonial marginalisation practices and policies (Sharma \& Wright, 2008). If we give good look around us, this notion is very real if we critically analyze the systems of modern day slavery and discrimination in forms capitalism and neoliberalism, forced labour, refuge-ness, and the definitions of 'good' and 'bad' migrants. Without questioning the settler colonial logics of the state, these discourses (re)imagine and (re)produce the same nationbuilding narratives that the state produces and maintains (Lawrence \& Dua, 2005).

\section{c. 'Multiculturalism', 'Integration' and Immigration}

Canada is the first country to adopt a multicultural approach towards diversity, which meant integrating the minority groups while they maintain their own cultural practices (Hiebert, 2016). The Multiculturalism program is the most important program in the Canadian Heritage 
Portfolio for the 'integration' of newcomers in Canada (Biles et al., 2008). The concept of multiculturalism was first proposed as a policy in the Canadian Charter of Rights and Values by Liberal government, and was then passed into law through 1988 Multiculturalism Act by a parliament led by a conservative government. (Hiebert, 2016, p. 10). One cannot deny that the policy of multiculturalism has been successful to create a surreal image of Canada as a haven for people of different race and colour. Srikanth (2012) argues that in previous decades multiculturalism has gained considerable support among policy makers, liberal intellectuals and social activists in various parts of the world. Canadian governments have effectively used multiculturalism to promote Canadian political and business interests abroad. Multiculturalism has capably established a discourse that is very hard to challenge, critique or question. The growing popularity of the theory and practice of multiculturalism should not, however, make one lose sight of its discontents.

Schmidtke (2014) argues that the idea of Canada as the 'champion of multiculturalism' is misleading in various ways (p. 78). The motivations behind adopting multiculturalism as an 'official policy' status were clearly political rather than social (Wood \& Gilbert, 2005). Banerjee (2000) argues that amidst of Quebec's separatist struggles and large influx of third world immigrants in 70 's, multiculturalism has served the purpose of a double edged sword by muting the francophone national aspirations, silencing the Indigenous land claim struggles, and also a way to deal with the non-European immigrant arrival. Wood and Gilbert (2005) argue that the policy of multiculturalism can be seen implemented in three stages: demographic, symbolic and structural; therefore multiculturalism is experienced differently by immigrants, and perceived differently by the policy makers and scholars. Looking back into political history, the 
institutionalization of multiculturalism was very incidental. On a superficial level multiculturalism seems to remove ethnic barriers and provide a sense of legitimization to different immigrant groups. Thus multiculturalism became a powerful nationalist vision for Canada and therefore has been used by the state as a tool to fulfil their political interests (Wood \& Gilbert, 2005). Digging deeper based on scholarly observations, multiculturalism also served as a way to separate various groups and pit one against each other for political and social gains (Fleras \& Elliot, 1992, as cited in Denis, 2011).Although Canada has always had open arms while welcoming immigrants, however, the process remained very selective on the 'kind' of immigrants. Throughout the history, the immigrants from Europe were considered as 'ideal' immigrants. The non-European immigrants like Chinese men were only allowed as laborers and not fellow citizens for the construction of Canadian Pacific Railway (Knowles, 2016). Therefore one can argue that Canada's approach to governing migration was originally rooted in a European way of nation building; it is only recently that Canada has 'attempted' to separate its immigration policies from notions of national identity and developed ethos of 'diversity' (Schmidtke, 2014).

The historical analysis of Canada's immigration past helps to problematize the presentday practice of race, and other discursive institutional and societal practices that contribute to marginalization of immigrants ( Krysa et al, 2019). Krysa et al (2019) argues "race and its colonial ideological principles continue to play a crucial role in immigrants' experiences and their integration process in Canada" (p. 98). Racialization is "the process by which societies construct races as real, different and unequal in ways that matter to economic, political and social life (Ontario Human Rights Commission, 2018). Racialization thus categorizes the self and the 
other based on biological features and therefore creates real societal structures that give preferable treatment to the in-group members while marginalizing the 'other'. Krysa et al. (2019) argue that upon arrival to Canada the non-white immigrants become part of the discourse of race that legitimizes the political process of differentiation. Under the discursive practice of 'diversity' in Canada, 'whiteness' serves as the norm and the point of reference, therefore depicting the white population as 'raceless', where 'others' represent a deviation from such standard (Nkomo, 1992; Mukherjee, 1994; Zanoni et al, 2010 as cited in Krysa et al, 2019). The next part of the chapter explores how Canada's national identity as a settler society with the neo colonial notions of 'diversity' and 'multiculturalism' dominates the discourse of 'integration' of immigrants.

\section{i. Economic 'Integration' of Immigrants}

Employment is a critical factor in the well-being and 'integration' of immigrant families. There are many challenges that influence whether newcomers successfully enter the labour market, including the non-recognition of foreign credentials and work experience, the demand for Canadian work experience, a lack of cultural capital, and racial and other forms of discrimination (Bauder, 2006). In the era of neoliberal globalization, precarious work has become an important feature of the market economy in many countries including Canada (Krysa et al., 2019). The neo liberal policies have created an increase in temporary, contract based parttime work with decreased interference of state into the labour market regulations (Galabuzi, 2006). These changes have resulted into what Galabuzi (2006) calls 'racialized job ghettoization' that forces the racialized individuals to work in vulnerable, precarious and underpaid jobs. It is evident that the state institutions have been "unable to design a successful integration strategy" 
that would focus on evaluating the competencies of trained immigrants rather than just validating the "demands for undefined Canadian experience" (Galabuzi, 2007, p. 131). Therefore, the educational credentials, and work experience from the countries of origin is considered of value only until the completion of application process for permanent residency; afterwards the education and experience are doomed to be incompetent with the 'Canadian' system.

The orientalist understanding of the self and the 'other' legitimizes the devaluation of different kinds of knowledge, degrees, and experience. One of the major features of Canadian integration model is gaining 'Canadian experience'. The concept and legitimacy of 'Canadian work experience' in itself reveals colonial binary and discursiveness embedded in so-called nondiscriminatory inclusive labour market (Bhuyan et al, 2017; Sakamoto et al, 2010 as cited in Krysa et al., 2019). Adib-Moghaddam (2011) argues that the Canadian concept of credential assessment can be understood as the carrier of epistemological meaning of the value of 'knowledge acquisition' from the places of 'other'. The Eurocentric institutions of power define what constitutes legitimate knowledge; thus, how we understand the 'West', and 'developing countries' carries epistemological meaning. The 'West' is viewed as superior and the centre against which 'developing countries' and its citizens are understood and evaluated (AdibMoghaddam, 2011; Said, 1978). Such monolithic understandings of 'others' affect the economic and social status of racialized immigrations today.

Rietz (2011) argues that since 1980's, immigrants' socio-economic success has been worsening in Canada. In 1980, new immigrants to Canada were earning 80 percent of what Canadians earned, however, in 1996, this number feel to only 60 percent (Rietz, 2011, p. 99). In the recent years, the proportions of skilled immigrants working in low income and low skilled 
jobs have drastically increased relative to Canadian employees. Galabuzi (2006) and Reitz (2011) identified this trend as "brain waste" or "taxi-driver syndrome", where highly skilled immigrants work in precarious low paid jobs because of inability to find meaningful jobs in their area of expertise. "Race is interpreted as the common denominator in explaining the poor labour market performance" (Galabuzi 2006; Thobani, 2007).

Data shows that the skilled non-white immigrants from the south do not experience the same economic success as immigrants from European heritage (Galabuzi 2006; Reitz 2011). According to the 2006 Canada census, 22 percent of racialized persons lived in poverty compared to 9 percent of non-racialized persons (Government of Canada, 2013). Block and Galabuzi (2011) refers to this phenomenon as "racialization of poverty", where 'race' is a crucial factor for disproportionate concentration and reproduction of poverty (p. 15). Furthermore as noted by Halli (1999) the poverty in Canadian immigrants seems to transmit from one generation to other, thus creating a state of social exclusion. This social exclusion as explained by Amartya Sen (2000) "needs to understood in the sense of capability deprivation, which not only impoverishes individuals or groups but also erodes their ability to escape the state" (As cited in Biles et al., 2008, p. 9).

As claimed by the Canadian integration model, a successful integration model ensures a positive-sum game for both the immigrants and the Canadians of longer tenure (Biles et al., 2008, p. 273). However the immigrants' experiences portray a different reality where the immigrants are expected to assimilate into the Canadian job market in a survival model, without dismantling the systemic 'integration' barriers imposed based on race, class, ethnicity, and country of origin (Biles et al., 2008, p. 275). 


\section{ii. Social 'Integration' of Immigrants}

In the early 1970s Trudeau defended Canada as a neutral multicultural nation in which there is " no official culture, nor does any ethnic group take precedence over any other" (Denis, 2011). Canada officially calls its racialized peoples 'visible minorities' or 'racial minorities'. However, one needs to ask what it means to be a 'minority'? Galabuzi (2006) argues that "Minorities are socially constructed entities in societies, and the label implies the imposition of an inferior status" (p. 31). Therefore the differences in race, gender, culture, and religion are used by the majority group to 'other' the minorities groups, and maintain power and privilege. Some might argue that minority status is dependent on numerical inferiority; however the settlement and population trends in Canadian urban cities might defy this claim. Despite the growing numbers, the inferior socio-economic and political situation of racialized groups ensure their 'minority status'(Galabuzi, 2006). John Porter described the construction of Canadian society as a 'vertical mosaic' where the founding groups, English and French are at the top, Eastern and Southern Europeans in the middle, racialized minorities and Aboriginal peoples at the very bottom who are most economically, socially, and politically disadvantaged. J.S Woodsworth, a reverend and politician in Canada at the beginning of the twentieth century reflects his views on immigration arguing that:

British immigrants are "among our best citizens" (Woodsworth, 1972, p. 46; originally published in 1909), while the Scandinavians "easily assimilate with the Anglo-Saxon peoples and readily intermarry" (p. 76). On the other hand, Polish immigrants have a complicated relationship with Canada, so it is "quite difficult for us to think of the people of this nationality other than in that vague class of undesirable citizens" (p. 114). Persians are "not fitted for life in Western Canada" (Woodsworth, 1972, p. 139), and the "Orientals" (referring to Chinese, Japanese and Indian immigrants) "cannot be assimilated" because they have "their own moral standards and beliefs" (pp. 154-155). (As cited in Krysa et al 
2019 p. 103).

The institutionalization of terminology 'visible minority' reveals its colonial meaning and the affects it still have on the present day Canadian society. The controversial issue around the redesigning of \$100 bill in 2012 serves as an excellent example of "trace of whiteness" in present day societal norms of Canada. It was evident through various focus groups throughout the country that the picture of an Asian female scientist "did not represent the Canadian society" (Asian-looking woman, 2012 as cited in Krysa et al., 2019). In response, the Bank of Canada changed the design on the note and indicated that it would " avoid depicting any specific ethnic group in such designs" (Asian-looking woman, 2012 as cited in Krysa et al., 2019, p. 104). Krysa (2019) argues that this example depicts the prevalence of race-based centre-periphery relationship in Canada, where the white person serves as a neutral centre, and the ethnic communities as unfamiliar peripheries.

\section{iii. Cultural 'Integration' of Immigrants}

Cultures "are continuously contested, imagined and reimagined, transformed and negotiated both by their members and through interaction with each other" (Dhamoon, 2006, p 361). The cultural identities are hence socially constructed and associated with the fluid culture. The 'culture' and 'multiculturalism' are often used to package those who share some aspects of identity without adequately addressing historical and contemporary forms of racism, colonialism, and imperialism (Dhamoon, 2006, p. 358). Narayan (2000) introduces the concept of "imposing sameness" through "packaged pictures of cultures", where cultures are 'frozen' neatly as wrapped packages, sealed off from each other without examining the variations in worldviews and ways of life (p. 1084). Kymlicka (2000) argues that the concept of culture is very well 
intertwined with idea of racism and racialization, therefore creating a grid and horizon of difference. The 'dominant cultures' become normalized and the 'minority cultures' are continuously 'othered' and measured against the 'norm'.

Cultural competence and cultural participation are one of the top two indicators while measuring cultural 'integration’ of immigrants (Biles et al., 2008, p. 275). Thobani (2007) argues, "the failings of outsiders are seen as reflective of the inadequacies of their community, of their culture, and indeed of their entire 'race'. Conversely, their successes are treated as individual and isolated exceptions" (p. 6). In Canada, the 'honour killing' tragedies of immigrant women and the rhetoric around those cases serves as a striking example of how some cultures and religions are 'believed' to hinder the 'integration' of immigrants in Canada. Unlike other gendered violence, 'honour' crimes are linked directly to certain religions, ethnicities and nationalities. Looking into the 'honour' killing case of Jaswinder Kaur Sidhu (2000), Aqsa Parvaz (2007), and Shafia sisters (2012), it is evident how these tragedies were lost in blaming the 'culture' talk. Interestingly, after the 'honor' killing case of Shafia sisters in Kingston, Ontario, then Prime Minister Stephen Harper came forward and called 'honor' crimes as 'barbaric' and 'henious', and something that does not happen in Canada (Globe and Mail, March 15, 2012). Thereafter such terminology was added to Canadian citizenship guide, which further fomented a debate on the wearing of niqabs during citizenship ceremonies. Walia (2013) argues that the highlighted focus of 'honour' crimes as 'barbaric' cultural practices in the political framework is strategically used to reinforce anti-immigrant, Islamophobic and war-mongering agendas of the west.

Similarly in the media, 'honor' killings are portrayed in ways that posit stark differences 
between the immigrant and the majority community. Mary Rogan's article, Girl Interrupted (2008) in Toronto life displayed an overtly overwhelming display of Parvez's personal photos in a sensual way. Additionally the article exhibits a very unilateral vocabulary and understanding of the crime. Rogan (2008) states "Canada prides itself on its multiculturalism and to varying degrees of success, condemns institutionalized patriarchy. But there is growing concern that recent waves of Muslim immigrants aren't integrating, or embracing our liberal values" (p. 54). Comparably in Jassi Sidhu case, the couple's private honeymoon pictures were circulated across various newspapers and news channels; following a comment in a news article, "This is the kind of cultural difference that sets many Canadians against more immigration" (ipolitics, 2018). Very conveniently, the entire burden of responsibility of crime is imposed on the 'barbaric' acts of people of a certain 'culture' and 'religion'.

This unidimensional analysis and over-emphasizing of culture-as-ethnicity/ nationality/language promotes what Kimberle Crenshaw calls "intersectional invisibility," in which the interactions between gender, race, and class discrimination become hidden and made imperceptible (Dhamoon, 2006, p. 356). Kymlicka (2000) explicitly states that the recent years have seen a shift from racialism to culturalism, where "cultural racism" has come to replace other direct forms of racism. The concept of multiculturalism leads to "Cultural Imperialism" which through the categories such as "western culture", "non-western culture", "liberal culture" focuses on the differences and inferiority of 'others' to western subjects (Narayan, 2000, p. 1083). This colonially inflected discourse establishes a civilizational 'norm' and 'superiority' which is sustained by the conceit that the 'west' tolerates the 'eastern' practices, and the Christians tolerates the Muslims in the west (Brown \& Strega, 2005, p. 186). Brown \& Strega 
(2005) further argues that in political and social settings, the 'capacity of tolerance' in itself is an expression of power and superiority (p. 189). Susan Okin's work on multiculturalism brings into light an interesting argument that "'nonliberal' societies are cultures; 'liberal' societies are states, civil societies and individuals" (Brown \& Strega, 2005, p. 190). This gives an answer to why always the instances of 'barbaric' cultural practices are always found on the 'non-western' side. The 'cultural' annotations thus attack the individual autonomy, rights and liberties of 'nonwestern' cultures (Brown \&Strega, 2005, p. 194). Himani Bannerji (2000) calls to de-construct the concept of 'culture' and call into question the reproduction and circulation of identities, differences and the contexts of 'power'. All societies are becoming increasingly multicultural, while at the same time becoming more porous. Therefore the differences should be recognized but in such away so as not to threaten the existing order (Dhamoon, 2006, p. 363).

The 'homogenized' immigrant communities are blamed for 'not willing to 'integrate' in the Canadian society. The 'willingness to integrate' therefore becomes an indicator of moral character of the immigrant groups which is further used for discrimination, hierarchization and crimininalization of migrants. In the post $9 / 11$ world, the public discourse has moved from ethos of diversity towards a top down security approach where multiculturalism is viewed as a threat to the integrity of the society. Leon Ang's (2015) research on securitization of Mexican migrants discloses how securitization dehumanizes the migrants, therefore creating a collective resistance that is built on common memory out of the tragedy. In this wake of 'backlash against multiculturalism', the 'integration' policies has moved away from a "public endorsement of cultural diversity and migrant's entitlements toward a stronger emphasis on state-monitored processes of 'integration' or the 'return of assimilation"” (Vertovec \& Wessendorf, 2010; 
Joppke, 2007; Triadafilopoulos, 2011 as cited in Schmidtke, 2014, p. 85). Hiebert (2016) claims that it is essential to build a firewall between the issues of immigration and 'integration' on one hand, and national security on the other. Having the same narrative in both the issues lead to negative consequences on the lives of racialized groups.

\section{d. 'Multiculturalism', 'Integration' and Indigenous peoples}

Denis (2011) argues that multiculturalism attempts to reduce the Indigenous communities to just one of many competing "minority" or "ethnic" groups within the nation. However this aspect of the multicultural policy clearly evades and erases the colonial history of land claims, systematic racism and cultural genocide of Indigenous people of Canada. During a press conference at the G20 Pittsburgh Summit in September 2009, Canadian Prime Minister Stephen Harper asserted: "We are one of the most stable regimes in history. There are very few countries that can say for nearly 150 years they've had the same political system without any social breakdown, political upheaval or invasion. We are unique in that regard. We also have no history of colonialism" (Henderson \& Wakeham, 2009). This statement was given just fifteen months before the apology for the residential schools in Canada. This public denial of the colonization of Aboriginal people can surely be reassuring to a selected group of people. Particularly to those invested in dominant Canadian historical narratives that continue to efface the history of illtreatment that Aboriginal peoples have endured at the hands of the Canadian state (Lozanski, 2007). The present mandate of Immigration, Citizenship and Refugees states clearly states to make changes in the system to reflect the Truth and Reconciliation's Calls to Action (Immigration Minister's Mandate Letter, IRCC 2017). However the changes will be solely superficial if we make them with a notion in our minds that 'we have no history of colonialism'. 
Palmater (2017) asserts "the goal of Indigenous assimilation and integration into "Canadian society" remains as the foundation of reconciliation platitudes underlying the new partnership moving forward" (The Decolonization and Reconciliation Handbook, 2017, p. 74) It is essential to understand that the goal of 'integrating' into the 'Canadian nation' in itself firmly cements the power status quo, while continuing to compromise the rights of Indigenous peoples uninterruptedly. Futhermore, Taiaiake Alfred (2017) calls reconciliation as a "tainted gift, and a false promise" by the government of Canada. He further claims:

Reconciling with colonialism cannot heal the wounds the colonizers have wrought on our collective existence. The essential harm of colonization is that the living relationship between our people and our land has been severed. By fraud, abuse, violence and sheer force of numbers, white society has forced us into the situation of being refugees and trespassers in our own homelands and we are prevented from maintaining the physical, spiritual and cultural relationships necessary for our continuation as nations. (The Decolonization and Reconciliation Handbook, 2017, p. 11).

Rita Dhamoon explains this concept more explicitly by her concept of referring to Indigenous peoples as 'internal foreigners' who cannot be deported but instead be 'managed' by inferiorization and criminalization (p. 178). This analysis of the location of Indigenous people in the eyes of the Canadian state is an important starting point in determining whether immigration policy may implicitly re-inforce their marginalization.

The Indian Act of 1876 legalized the distinction between Indigenous and the rest of the population, which formally placed under the legislative and administrative control of the state that was characterized by the domination of Europeans, thus leading to destruction of their livelihood and the loss of autonomy (Patterson, 1972 as cited in Galabuzi, 2006). These legal structures in many ways display the continuation of 'democratic racism' in Canada, through 
coexistence of democratic principles and racist ideologies in the ideas of people and the practices of social institutions (Henry et al., 1995; Li, 1995; Zong, 1994 as cited in Galabuzi,2006).

\section{i. $\quad$ Economic 'Integration' of Indigenous peoples}

Arthur Manuel (2017) writes: “Colonialism has three components: dispossession, dependence and oppression. Indigenous people live with these forces every day of their lives" (The Decolonization and Reconciliation Handbook, 2017, p. 19). During the creation of what we call 'Canadian nation' today, the Indigenous people were subjected to the biggest land theft in the history of mankind; "from enjoying $100 \%$ of the landmass, they were reduced by the settlers to a tiny patchwork of reserves that consisted of only $0.2 \%$ of the landmass of Canada, the territory of existing reserves, with the settlers claiming $99.8 \%$ for themselves" (Manuel, 2017, p. 20). The massive land dispossession resulted in continued dependency, poverty, and disruption in their social, political, cultural and spiritual life. Even today, Aboriginal people remain the continued targets of state policy, since Aboriginal marginalization has occurred largely outside the discourse of Canada's multicultural success (MacDonald, 2014).

It is evident that while Canada is consistently rated as one of the top countries in the UN Human Development Index, Aboriginal peoples rank alongside citizens of Panama, Belarus, and Malaysia in terms of their social and economic prospects, and the gaps between the living standards of Indigenous people and the rest of the 'Canadian' population are not narrowing (Daschuk, 2013 as cited in MacDonald, 2014). Palmater (2017) notes that the First Nations have the lowest socio-economic indicators in Canada and some of the highest suicide rates in the world (The Decolonization and Reconciliation Handbook, 2017, p. 75). Additionally, Palmater (2017) adds that First Nations are subjected to federally controlled and chronically underfunded 
social programs and services that do not increase with inflation, actual costs or population increases (The Decolonization and Reconciliation Handbook, 2017, p. 76). It is evident through Hanselmann's report on "Urban Aboriginal People in Western Canada" that there are visible distinctions between Aboriginal and non- Aboriginal populations in major Canadian cities. These distinctions are not unrelated to public policy (Hanselmann, 2001). The Canadian government has been historically hesitant in creating policies specific to urban Aboriginal people. There has always been confusion amongst the federal, provincial and municipal governments in taking the primary responsibility in this matter. This lack of agreement over responsibility has lead to “inconclusive activity" and a "policy vacuum" (RCAP, 1996 as cited in Hanselmann, 2001). The outcome of this policy void has been that urban Aboriginal people have largely fallen through the cracks.

What is more unfortunate is the fact that Indigenous peoples are held responsible for their lack of efforts to 'integrate' into the 'Canadian' society, which therefore is seen as a reason for their poor economic conditions. In a 2013 Huffpost article "why are Aboriginals afraid of integration", lawyer and Journalist Ike Awgu assert:

At some point, aboriginal Canadians need to consider that the best hope of a future for their children may be integration into the mainstream of Canadian socio-economic life. They need also understand that integration is not the same as assimilation..... No amount of meetings with the Prime Minister, "white papers", renovated treaties or twitter campaigns will give to Aboriginal people a standard of living commensurate with that of ordinary Canadians if they choose to live in the margins of society far away and disconnected from the mainstream of Canada.

Therefore, if practiced on a superficial level, reconciliation with a goal of 'integration' can act as re-colonization by allowing the colonizers to hold on to its attitude and mentality and 
by telling the Indigenous people that the historical problem has been fixed; whereas, the life experience of the Indigenous people may have gotten worse in reality, thus, Indigenous peoples must conclude that they are the problem (Alfred, 2017, The Decolonization and Reconciliation Handbook, 2017, p. 11).

\section{ii. Social 'Integration' of Indigenous peoples}

Despite the fact that Indigenous peoples had played a major role in establishment of European settlers, they were never included in the national imagination of the 'Canadian' nation (Bauder, 2011). In a 1920 speech to a Special Committee of the House of Commons, Deputy Superintendent General Duncan Campbell Scott said bluntly:

I want to get rid of the Indian problem. I do not think as a matter of fact, that this country ought to continuously protect a class of people who are not able to stand alone. . Our object is to continue until there is not a single Indian in Canada that has not been absorbed into the body politic and there is no Indian question, and no Indian Department. (Diabo, 2017, The Decolonization and Reconciliation Handbook, 2017, p. 23).

Historically and even today, the problem lies in the inappropriate manner the Indigenous histories are introduced, that helps the 'majority' to believe the negative portrayal of Indigenous way of life. Khan et al. (2015) writes: "They are viewed as irrational and backward because of their choices. Their communities are mislabelled as abusive, lazy alcoholics whose lack of political, social and economic power is self-inflicted" (p. 150). This limited access to knowledge perpetrates the dismissal of the colonial roots that are the underlying cause of the current economic, social, and political problems among the Indigenous communities (Khan et al., 2015). On a similar note, in a recent $2018 \mathrm{CBC}$ article, "'You don't belong here': Integrating Indigenous 'cultural humility' into health care", Jonathan Ore writes about the experience of Indigenous peoples: 
I think that the most prevalent [factors] in the stories we hear most have to do with the echoes of colonization.... Living in a racist environment — residential schools, poverty, isolation, lack of education and employment opportunities... Those are all factors in creating the pain that drives people to use substances to end pain.... We have a pain problem, not a drug problem. From an Indigenous lens, racism is part of our individual interactions, (and) our systemic interactions, and that's never going to change until everybody's on board.

Therefore, it is indicative that social 'integration' will always remain a 'problem' if we keep on finding the problems in the Indigenous peoples, rather than looking deeply into the structural barriers and neo colonial state imposed policies. The introduction of the term 'First Nations', the public apologies and the listing of Indigenous peoples as one of the three founding nations can be seen as an example of 'progressive officialization'; however, this form of multiculturalism fails to address and challenge the existing race based discriminatory practices within the society and historical injustices towards the Indigenous and racialized peoples (Thobani, 2007; Banerjee \& Linstead, 2001). Moreover it can be argued that the policies are themselves a very powerful way to shape borders of inclusiveness and marginalization in a society. Referring to Foucaudian concept of 'official procedures of exclusion', the regulation that defines English and French as Canada's official languages serves as a present day example of the concept. The Multiculturalism Act guarantees to preserve 'other' languages, however, this acknowledgement in itself creates a linguistic hierarchy of 'official' and 'other' languages in Canada (Government of Canada, 2015; Krysa et al., 2019). Although the Indigenous peoples have been recognized as one of the founding people of Canada, but Indigenous languages still remain as 'other' languages thus denying first nations a linguistic officialization within the multiculturalism discourse (Day, 2000, p. 183). 


\section{iii. Cultural 'Integration' of Indigenous peoples}

Canada often boosts about its cultural diversity, however, the cultural 'integration' of Indigenous people is often promoted through shallow means of reconciliation by changing the names on the buildings, placing the art work on currency, wearing Indigenous designs of clothing (Palmater, 2017, The Decolonization and Reconciliation Handbook, 2017 p.74). The Indigenous people, their culture and traditions are often seen as a thing of past and their presence as the 'first people' of Canada is not adequately acknowledged; they are often told to "get over with it" and 'integrate' into the mainstream for a better future (The Decolonization and Reconciliation Handbook, 2017, p. 74).

In a 2013 Huffpost article "why are Aboriginals afraid of integration", a lawyer and Journalist Ike Awgu, states:

No one is forced to assimilate in modern Canada. Tens of thousands of people from all over the world, from places that have living conditions worse even than those found on reserves, immigrate to Canada and find success. These people care no less about their culture of origin than aboriginal people do theirs. They care no less about their history than aboriginal people do theirs. They care no less about their traditions and language than aboriginal people do theirs. Have they been "assimilated"? Their future lies in independence, the independence gained by wealth, success and yes, integration.

The absence of comprehensive education, paired with a general ignorance about the history, colonization, assimilation, and displacement of Aboriginal Peoples in Canada makes immigrants and long term Canadians both complicit in and active participants of the colonial project (Khan et al., 2015). In the race of becoming a good Canadian citizen, the immigrants are often pitted against Indigenous peoples therefore suggesting that they are just another minority that does not want to 'integrate'. 
In the article, "Categories and Terrains of Exclusion: Constructing the 'Indian Woman' in Early Settlement Era in Western Canada", Sarah Carter (1996) presents how the Indigenous women were completely disregarded in the early years of making of the Canadian nation. Unlike a trading colony, the presence of women was extremely significant for a settler colony to flourish. Although it was evident that the white men had relations with Aboriginal women, bought and sold them, and lived with them; however when it came to building the nation and raising a family they didn't seem to be the right fit (Carter, 1996). Robert (1979) argues that as the family was the cornerstone of the nation, and the British women being the bearer of this family, bear the responsibility of building the nation and the empire. The ultimate significance of this work was in safeguarding the future of the race and building the nation upon culturally imperial lines (Roberts, 1979). The concept of Canadian nation building was tied together with the discourse of racial purity, therefore constructing the Anglo-Saxon women as the 'mothers of the race' (Dua, 2000). As it is said 'The nation is home, and the home is the women'; the social and biological reproduction of Indigenous women was perceived as threat to the 'culture' Canadian nation. 


\section{Chapter 4: 'Integration' in German Context}

\section{a. Germany \& Colonialism}

With Germany's very short period as a colonial power from 1884 to 1919 , it may seem trivial to talk about colonial discourse and decolonization projects in its context. However it is important to understand how the 'short-lived' colonial projects can produce long lived affects on the mentality, and imaginary configurations that linger long after. German historian Jürgen Osterhammel defines Colonialism as a multifaceted 'phenomenon of Colossal vagueness', “a 'system' of techniques and ideologies of political, economic, social, emotional and cultural subjugation, and of common habitual practices of colonizers and of their effects on the colonized subjects" (Kühne, 2013 p. 346). Baumgart asserts that colonies remained an important factor in German Weltpolitik (imperialist foreign policy) in 1890s, where nationalism was defined as "a motive power of the German people to spread influence all over the globe" (Friedrichsmeyer, Lennox \& Zantop, 1998, p. 22). In a recent survey by Osterhammel on European colonialism, he concludes that "colonialist thinking is deeply embedded in the mind set of colonizing nations" which is manifested in various ways like construction of an inferior otherness, colonizing 'mission', mandate of guardianship, and utopian notion of natural order (Friedrichsmeyer, Lennox \& Zantop, 1998, p. 18). These symbolic constructs of Imperialistic imagination as understood by Benedict Anderson and Jacqueline Rose creates "a national identity that is a product of collective, albeit largely unconscious, efforts to imagine and define national interest, national desires and a collective will (Friedrichsmeyer, Lennox \& Zantop, 1998, p. 18).

Despite failed colonial endeavours, the colonial 'fantasies of nations' remained alive in Germany. The colonial fantasies inspired ideologies of racist suppression, racial hierarchies, 
colonial stereotypes, and even annihilation. (Kühne, 2013, p. 344). To this day, German orientalist texts are treated as 'exoticist' pieces of literature (p. 51). Thus the national imagination of identity is tied closely with power and superiority in the world order, 'natural' right over the weaker and less advanced or uncivilized. Even after forced relinquishing of colonies after World War I, the obsession of 'Germanness' still continued. Unlike England and France, the architects of German national history did not come from elites, but from educated middle class, the Bildungsburgertum, that assumed the leadership in urging and molding the German national consciousness and identity (Kühne, 2013, p. 345).

A team of researchers at the University of Berlin revealed that there are various ideological, scholarly and personnel continuities from Kolonialwissenschaften ('colonial sciences') in Imperial Germany to Ostforschung ('Eastern research') in Nazi Germany. (Kühne, 2013, p. 342). In the monologues between 1941-1944, Hitler was known to brag about the soonto-be conquered German Lebensraum in Russia as 'our India', "Just as the English rule it (India) with a handful of people, we will rule our colonial space" (Jochmann, 1980 as cited in Kühne, 2013). The British indirect rule on the subcontinent served to him as an example of imperial efficiency. Similar to colonialism, Nazism also assigned 'racial status' to their subject, which was then used to persecute, humiliate, and subjugate the subjects (Kühne, 2013, p. 346). Although the systems of exploitation, techniques of appropriation and misappropriation, and degree and strategy of annihilation may differ and are incomparable in various ways, however, it is evident that they both worked out of same apparatus of ideologies.

Kakel (1997) makes an interesting connection between the 'The American West' and 'The Nazi East' by making a rare systematic comparison between the Nazi genocide and North 
American colonial genocide (as cited in Kühne, 2013 p. 347). Kakel deploys the concept of settler colonialism to analyze the close connection between the territorial expansion and destruction of Indigenous peoples; in both the contexts, the genocidal assaults against the unarmed civilian populations were justified by the obsessions of racial superiority by militarily defining them as 'unwanted demonized enemies' (Kühne, 2013, p. 348). Another similarity comes with the continuity of the "myth of an empty space", first introduced as a justification of colonialism by John Locke to theorize the occupation of the 'unclaimed' lands that are not ruled by law, therefore the lands belong to 'no one'. The Hitler-Stalin pact of August 1939 illustrates that the Nazi conquest moved a step further from the spatial paradigms of colonialism, and actively emptied the lands, and so did the Settler colonial conquest in North America (Kühne, 2013, p. 351). Lastly, one can argue that the search of continuity from colonialism to Nazi conquest can lead to chicken-and-egg problem, thinking which came first: racism, nationalism, imperialism or colonialism; but one thing that remains certain is the underlying continuity of ideologies in both the events (Kühne, 2013, p. 356).

\section{b. 'German Ethnic Nation' and Immigrants}

In the past few decades, Germany has implemented drastic changes in its immigration policies, citizenship legislation, and has made enormous progress in the social inclusion and integration of non-Christian immigrants. Germany played a major role in "European attempts to harmonize immigration policy" during the implementation of Schengen agreement in 1995 (Bauder et al., 2014). However, to some extent in recent immigration debates, Germany still holds on to its idea as an 'ethnic' nation that has historically being hostile to receiving 'nonethnic' Germans. 
Unlike Canada, Germany's national identity is not framed by immigration. For most of the modern history, Germany has been described as an ethnic nation; the German name for 'Germany', 'Deutschland', "refers to the 'land' of the people who are 'deutsch' (i.e, German)" (Bauder, 2011, p. 4). Therefore the connection between the national territorial belonging and ethnic identity is explicit in the name of the country, and immigration does not play an important role in defining the German nation (Bauder, 2011, p. 4). Germany follows the ius sanguinis principle (law of blood) for passing citizenship from one generation to another (Bauder, 2014). German Scholar, Christian Joppke remarks that "the German state has responsibility to the people who are historically connected to it; otherwise 'it would be a nameless cash register for the transactions randomly occurring on its territory"' (Dauvergne, 2005: 226 as cited in Bauder 2011, p. 6). Therefore the national 'ethnic German' identity remains a key variable in explaining the inclusion and exclusion of migrants historically and even today. After the end of blatantly xenophobic catastrophe of the holocaust and the genocides committed by Nazis, the exclusion of non-ethnic Germans continued in a subtle manner. After the Second World War, this ethnic principle of national belonging enabled the integration of almost 15 million German refugees who lived in Eastern Europe but fled to the West Germany after the Soviet occupation. On the other hand, the same principle was also the basis of exclusion of about 13 million Turkish 'guest workers' between 1955 and 1973 (Bauder, 2014). Even the German born children of 'guest workers' who chose to remain in Germany were excluded from the national imagination and membership in the national polity (Bade, 1997 as cited in Bauder, 2011). Furthermore after the discontinuation of guest worker program in 1970's and 1980's, the workers were labeled as 'foreigners' (Ausländer) and as "bogus asylum seekers" (Scheinaslylanten) or "economic 
refugees" (Wirtschaftsflüchtlinge) who were no longer needed in the country (Wengeler, 1995 as cited in Bauder, 2014).

However in 1990's, Germany's immigration discourse came under scrutiny "when the newly arrived ethnic Germans were privileged over foreigners who lived in Germany for generations" (Bauder, 2014, p. 14). These discussions later led to constitutional change in Germany in year 2004, by introduction of the Zuwanderrungsgesetz, an immigration law that was suppose to enable large-scale immigration into the country (Bauder, 2014). However Bauder (2014) marks an interesting progression of Germany as an "immigration country"; followed by a rebuff that Germany remains a "non-immigration country", and a final resolution that Germany is an "integration country" (p. 18). The label of an "integration country" serves as a convenient label that satisfies both its positions, immigrant and non-immigrant, and thus outshines the fact that 'immigration is possible, but conditional' (Bauder, 2014).

Immigration and integration still remain very divisive topics in Germany. There was rarely a time when Germany did not need migrant workers to keep its economy going. Germany still needs immigrant workers "to maintain its position as Europe's strongest economy" particularly keeping in mind its aging population and declining birth rates (Campbell, 2012, p. 451). Unlike Canada where the immigrants are seen as economic drivers, the economic benefit of immigration is still a debated subject in Germany (Bauder, 2014). "The value of foreign labour lies precisely in the social and political marginalization of the people providing this labour: by not extending political, social and economic rights to foreign workers, they are more exploitable than German citizens and in this way facilitate capital accumulation" (Bauder, 2006b). Over the debate of Deutschland schaff sich ab (or Germany Abolishes Itself), a potently anti-immigrant 
publication authored by prominent banker Thilo Sarrazin, one thing has been clear that migrants should only be seen working, but not otherwise (Kritnet, 2013)

\section{c. 'Multiculturalism', 'Integration' and Immigration}

In Germany, the public debate around multiculturalism has made one thing clear that “foreigners are here to stay” (Kastoryano, 2018). According to Kymlicka’s (1995) typology, Germany can be classified as a polyethnic state with large numbers of post-colonial migrants that represent different collective identities, religions and claims (Kastoryano, 2018). The shift from temporary economic immigration to permanent presence has marked a need for developing a narrative and policy that considers migrants as co-citizens. With the formation of Federal Office for Migration and Refugees (BAMF) in 2005, 'integration' for the first time was defined as 'a governmental task' in Germany (BAMF, 2018). After a long conscious denial of permanent residency of guest workers in Germany, the German National Integration Plan in 2005 marked as a first step towards a high profile, multi-sectoral integration summit. It centers on 700-hour 'integration' course, designed to provide and test "sufficient knowledge of the German language and... about everyday life in Germany, as well as concerning the legal system, culture and history of Germany and the principles of rule of law, equal rights, tolerance and religious freedom" (Kohlmeier et al., 2006, p. 24). The 'integration' courses are funded by the federal government and offered by third sector agencies; the courses have been made mandatory to the newcomers without knowledge of German language. The Federal Office for Migration and Refugees (BAMF) reported that on the onset of program about 700,000 newcomers participated in the program. Green (2005) finds that German settlement discourse, underpinned by the ethos of 'integration', is concerned with "the extent to which non-nationals should be expected to 
assimilate (i.e take on the majority culture), and how the norms to be accepted by all immigrants or non-nationals ... should be defined" (p. 199). Dutch researchers Hans Vermeulan and Rinus Pennix observes that the term 'integration' was introduced in several European countries to replace 'assimilation', in order to “indicate a greater degree of tolerance and respect for ethnocultural differences" (Alba \& Foner, 2015, p. 19). However despite this narrative there is a considerable degree of overlap between the assimilation and integration concepts (Alba \& Foner, 2015, p. 20).

\section{i. Economic 'Integration' of Immigrants}

The National Integration Evaluation mechanism (NIEM) 2018 report in the European Union evaluates integration in three different dimensions: Legal integration: residency, family unity and reunification, access to citizenship; socio-economic integration: housing, employment, vocational training, health and social security; and socio-cultural integration: education, language learning and social orientation and building bridges (http://www.forintegration.eu/pl/about-theproject). Out of all these, it is evident that the economic 'integration' of immigrants remains the top most priority of BAMF. In 2016, German Federal Labour Minister Andrea Nahles pointed out:

'Work is the best means of integration', therefore successful integration meant that went from receiving social benefits to putting a great deal back into society (Press and Information Office of the Federal Government- Bundesregierung, 2016).

One cannot deny that economic motivation is one of the paramount reasons most migrants relocate from their country of origin (Alba \& Foner, 2015). However the problem under the 'integration' rhetoric surfaces when the immigrants are depicted as 'burden' on the 'host' society, therefore they should start working under any circumstances to 'give back into the 
society. Alba and Foner (2015) explains this as the process of 'immigrant bargain' where under societal pressures, the immigrants are willing to accept low level jobs in order to succeed and 'integrate' in the 'host' country (p. 61). Many activist lobbies have argued that these measures project unwillingness to integrate on newcomers "when the real problem lies with the government's failure to provide adequate training, support and job opportunities" (Wagstyl, 2016 as cited in Kastoryano, 2018).

A comparative study in Europe shows that the integration policies promoting multiculturalism have not improved the economic situation of immigrants, instead, have resulted in political and cultural marginalization (Koopmans, 2010 as cited in Kastoryano, 2018). Labour market inequality is a growing concern all over Europe; recent statistics show that in Germany 23 percent of workers work in low-wage labour i.e part timers, earn low wages (Alba \& Fober, 2015, p. 64). The labour market developments and immigration go hand in hand, thus, the number of immigrants working in low wage job is disproportionately higher than the 'majority' population. In Germany, the immigrant-native employment gaps are longstanding even among the guest worker groups, who came to Germany in 1950s recruited as workers in the first place (Alba \& Fober, 2015, p. 71). Additionally, Alba and Fober (2015) discusses "the rigidly stratified German educational system generally has proven difficult for the children from immigrant homes to navigate and produces one of the highest native-/immigrant-origin differentials (p. 249). Futher suggesting that this highly stratified structure of the educational system "seems to be at the heart of the educational disadvantages that the children of Turkish immigrants experience, disproportionately concentrated as they are in the lowest track of a threetiered system" (Alba \& Foner, 2015, p. 254). Statistics show, the unemployment rate among 
Turkish population is twice as high as the young Germans' (Stehle, 2006). Despite the high visibility of Turkish small businesses, Turks are still underrepresented in the small business as compared to their population (Alba \& Fober, 2015, p. 80). Therefore many immigrants are forced into irregular or informal forms of work, which are 'off the books' and pay below the minimum wage and lack healthcare, pension, and other benefits. In Germany, this kind of work is designated as schwarzarbeit or 'black work' which is often seen as a common among undocumented migrants or legal resident turks (Alba \& Fober, 2015, p. 68).

\section{ii. Social 'Integration' of Immigrants}

Phillips (2007) argues that multiculturalism is not only about the 'inclusion of immigrants into the mainstream and protecting their rights', it also relates to the differences in the groups. Under the multicultural policy, these differences take the form of legal categorization such as citizen and immigrant, national and non-national, citizen and non-citizen; hence placing the immigrants in the 'other' category. Such categories create and maintain "identity boundaries" locally and nationally (Kastoryano, 2018). One example of this phenomenon is the social reality of concentrated and segregated neighbourhoods or 'ghettos' where the immigrants or migrants are forced to live due to social and economic pressures. Kastoryano (2018) argues that the ethnic grouping in such neighbourhoods reflects the failure of multiculturalism and the integration policies influenced by it.

The ghetto-discourses allows one to understand the linkage between the 'imperial racial system' and the construction of internal borderlines on the periphery of the 'metropolitan heartland' of Europe (Winant, 2001 as cited in Stehle, 2006). These discourses reveal how “new racisms create and recreate certain kinds of ghetto-spaces that duplicate, mimic, and enforce the 
external borders of Europe" (Stehle, 2006, p. 50). The word, 'ghetto' gets its origin from the Hebrew word 'ghet', which means reclusion; in order words refers to 'incarceration as a punishment for crime'. The word was first used for Jewish quarters in the $16^{\text {th }}$ century Venice, and later in connection with the ghettoization of European Jews during Nazi regime. The term 'ghetto' is often used interchangeably with 'slums'; however, the German Duden

Fremdwörterbuch defines 'slums' as 'poverty ridden neighborhoods in large cities,' whereas a 'ghetto' is defined as 'area of the city in which a racial or religious minority is forced to live.' (Stehle, 2006, p. 51).

The German author and essayist Peter Schneider in his article, 'The New Berlin Wall' in the New York Times describes the internal borders of Germany:

There is a new wall rising in the city of Berlin. To cross this wall you have to go to the city's central and northern districts - to Kreuzberg, Neukölln, and Wedding - and you will find yourself in a world unknown to the majority of Berliners"(Schneider, 2005).

Since 1970's, the 'Kreuzberg Turkish ghetto' has been always remained a topic of discussions for 'Ethnic' Germans, politics, and social workers. The ongoing discussions have raised concerns about the growing number of undocumented immigrants, and the issues of hygiene, poverty, unemployment, decaying houses, crime rates, and 'foreignness'. It is essential to realize that the meaning of 'integration' changes when such conditions are generalized, thus creating the perception about migrants that links increasingly to the question of identity and participation and then to the question of security (Zapata-Barrero 2017, Kastoryano, 2018). In 1970s an article in Der Spiegel, a German weekly news magazine, 'Ghettos in Germany: One Million Turks' was introduced with an alarming slogan: "The Turks are coming - save yourself, if you can" (Stehle, 2006, p. 51). The Ghetto somehow appeared as "the marked space, the 
ultimate nightmare, a dangerous space, which 'we' cannot or should not enter, in which 'we' are not safe, and a space where 'integration' has clearly failed”. (Stehle, 2006, p. 51). Commenting on the 'ghettoization' of migrants, the Federal Minister of the Interior, Thomas de Maizière highlighted that there are two realities of 'Integration' in Germany:

One where the refugees have taken advantage of the opportunities available to them, they have done vocational training or learned a trade. They are studying for a degree or have set up a business that employs people. They are helping Germany to grow. They are an enrichment to our country. Whereas he said there is another reality, People were able to live here without integrating into society. They hardly spoke any German or did not want to. And they don't have a proper job. A few young men are responsible for a remarkable number of criminal offences. These insights into the two realities that exist in our country are painful, the Minister said (Press and Information Office of the Federal GovernmentBundesregierung, 2016).

However rather than focusing on the structural reasons for unemployment, crime rates etc., the threat of 'emerging ghettos' fostered a discussion around preventing certain groups of people from 'crowding' certain neighborhoods therefore negatively affecting the process of 'integration'. However, in the narratives of 'integration', it is important to explore the underlying causes of lack of geographic mobility. Undoubtedly, the ethnic enclaves provide temporary harbor to migrant families facing economic and societal pressures of prejudice and discrimination the 'host' country (Alba \& Foner, 2015, p. 108).

\section{iii. Cultural 'Integration' of Immigrants}

Bauder (2011) asserts "the cultural mismatch between immigrants and German society has been a long established idea" (p. 174). Martin Wengeler (2006) wrote about the anxieties in 1960's and 1970's about 'unwillingness' of immigrants to 'integrate' in the German society, whereas forming parallelgesellschaft or parallel societies, "in which immigrant communities 
exist without significant contact with German civic society" (As cited in Bauder, 2011, p. 174).

Although Germany has a come a long way since 1970's, however, the rhetoric around 'unwillingness to integrate' remains cemented in the immigration debates. The current BAMF website states:

The German government is creating a powerful incentive to integrate with regard to unlimited settlement permits. Only those recognised refugees who have shown they are willing to integrate will be given a settlement permit (Press and Information Office of the Federal Government- Bundesregierung, 2016).

Therefore, in other words, the issuance of the settlement permit is dependent on the 'integration' of an individual. In this scenario, participating in the 'integration' programs is not a choice, but an obligation for the individual. The course is provided free of charge to some groups including ethnic German Aussiedler and those on unemployment benefits. However the others pay nearly two euros per hour, amounting to 1,365 euros over 700 hours (BAMF, 2018). If even the courses are completed, the migrants can still be denied permanent residency on the basis of lack of documentation, criminal charges or if they come from so called 'secure country of origin' (Prem, 2017, p. 122). Goodman (2010) notes that with limited naturalization possibilities, the integration courses are not solely 'functional'. But also represent 'political-symbolic' policy that offers 'welcome culture' only to those who can absorb the financial burdens of assimilation (p. 766).

The German government often identifies itself as a 'neutral' state when describing its relationship with religion (Kortmann, 2018). The Federal Office for Migration and Refugees BAMF (2018) acknowledges that culture has always been the centre of integration debate in Germany, with particular discussions about "German Leitkultur" and "whether 'Islam' is 
reconcilable with European values and ways of life". With almost 4.5 million Muslims in Germany, Islam is a very important part of country's fabric. Contrary to such claims, it has been evident that Christianity serves as a culture that has shaped the German society. In 2011, German Minister de Maiziere stated, "We are shaped by Christianity culturally, spiritually and politically" (Kortmann, 2018 p. 11). This statement in itself makes Islam a religion that does not 'belong' to Germany and is incompatible with 'German' cultural values (Brunn, 2012, Halm 2013, and Teszan, 2012 as cited in Kortmann, 2018). While connecting the aspects of danger and 'culture', the muslim immigrants are often portrayed as the 'others' in discourse of immigrant integration (Bauder, 2011, p. 174). For instance, after the 2005 bombing attacks on London's subway, a conservative candidate for German chancellor Angela Merkel asserted "The London attacks show that 'integration will be a central theme of the future'... every immigrant must commit to the values and the constitution of the Federal Republic of Germany" (Süddeutsche Zeitung, 2005 as cited in Bauder 2011, p. 174). The immigrants are still seen as 'others' and threat to the 'western' values of Germany; therefore the 'integration' is seen a tool to 'reduce the threat' level posed by immigration (Bauder, 2011, p. 174)

Schinkel (2018) argues that socio-cultural integration is measured by looking into the level of 'secularity' and 'modernity' of a person. This creates an assumption that, if Germany is a 'secular' country, the more 'religious' a person is, the less integrated he/she is in the society. For instance, the Turkish immigrants in Germany are always pointed out to not have enough contacts with the native population (Schinkel, 2013). It is interesting to see here that the integration researchers are not interested in 'interethnic contacts' but contacts of members of 'ethnic minorities' with the members of 'neutral' category. Another indicator of measuring socio 
cultural 'integration' is the ability of immigrants to make contacts with members of other groups, specifically the host society. As 'Ethnic Germans' and 'White Canadians' are seen as 'neutral groups' that do not need any 'integration', these groups are never measured and are not required to socialize with other ethnic groups. Therefore their lack of interethnic contacts has no consequence for them as they create a benchmark for the 'other' ethnic groups (Schinkel, 2018).

One can argue that in the debates around the 'integration of foreigners', the voices of people who are supposed to 'integrate' are completely absent. Calgar (2001) and Weber (2004) notes that "the agency of the migrant or the ghetto inhabitant is rarely a part of the discourse" (as cited in Stehle, 2006, p. 53). The historically operated narratives of 'whiteness' move across borders and create new borders, seeping into everyday lives of the immigrants through structural racism and exclusion. Without understanding the structural barriers in the society, the sole responsibility of integration is put on the 'foreigner' and therefore gets blamed to be a 'troublemaker' and those not 'willing to integrate'. Schinkel (2018) calls out to wake up from 'multiculturalism' as its discourse has entailed a license to problematize the migrant others, and sustains a classed and raced form of dominance that is precisely called 'native' or 'white'. Schinkel (2018) believes multiculturalism “to be self-declared 'realism' of supposedly having been 'multicultural' and hence 'politically correct', naively 'left-wing', 'ignoring the problems', daring to speak the harsh truth about the troubled realities of a failing model of immigrant integration" (p.2). The fiction of multiculturalism that was once dominant in Europe has now been shown to have failed, because of lack of 'multiculturalism' in policy nomenclature, let alone the practice (Schinkel, 2018, p.2) 


\section{Chapter 5: Conclusion and Discussion}

The different approaches, policies and attitudes of Germany and Canada towards immigration can be understood by their different historical understanding of nationhood. Both Canada and Germany are “liberal democracies with 'western' political traditions and principles and highly advanced capitalist economies", however, their different historical and geopolitical contexts have framed their national identities and belonging differently (Bauder 2014, p.10). With a history of settler colonialism, Canada's national identity is deeply connected to immigrants, thus proudly naming themselves as 'country of immigrants'. On the other hand, Germany identifies itself as an ethnic nation. It can be argued that both the settler societies and ethnic nations "include and exclude the new members based on the similar principles of sovereignty and self determination" however difference lies in 'who' is excluded and 'how' (Bauder 2011, p.6). Bauder (2014) states, "in Canada, the understanding of a settler society has been constructed in dialectical opposition to the Indigenous population; in Germany, the national imagination has tended to exclude immigrants without German ethnic roots.” (p.11).

Süssmuth remarks that it is these historical lineages in the national identity that influence the kind of migration and 'integration' policies a country adopts today (Bauder 2011, p. 5). The comparative analysis of economic, social, and cultural 'integration' in Germany and Canada exposes various gaps and traps created by the neo colonial understanding of 'integration' in today’s world. Firstly, both Germany and Canada prioritize economic 'integration' and make efforts to 'integrate' newcomers into the labour market by offering various skills development and language training programs. However these programs produce short term measurable results' 
over comprehensive long-term holistic programming; while employment programs can be seen as a good first step for the newcomer employment as a "matter of competition and organizational survival" but they fail to address the root causes of barriers into the labour market (Shields et al 2014, p.20; Trudeau and Veronis 2009, p. 1125). Secondly, in both the contexts 'integration' is seen as an individual responsibility of the immigrants. Although it can argued that Canada defines "integration as a two way street", however, the inclusion of new immigrants remain very superficial on behalf of the host society (Shields et al 2014). Thirdly, 'integration' is seen as a solution towards the perceived threats of immigration, therefore, 'integration' programs serve as technique for power for moral monitoring, criminalization, and hierarchization of the immigrants. Fourthly, in the Canadian context, Indigenous voices are completely missing from the discourse of 'integration', whereas they are themselves 'required' to integrate into the so called Canadian nation.

'Integration' is a 'choice' and something that occurs naturally through different social and cultural interactions over time. 'Integration' when imposed as an obligation takes a form of neocolonial practice monitored by the 'white' society. 'Integration' therefore becomes a form of present day colonialism that marginalize the racialized groups as 'others'. Richmond and Shields (2005) notes that it is fundamental to "make integration a two-way street" by activating social inclusion not only through government policy but also as a bottom up approach through participation of Canadian society (p.39). It is important that we imagine our societies against the grain and stop reproducing the same rhetoric of 'otherness' around immigrant integration; "any claim and practice that concerns 'integration' should be object of research, rather than the project of research" (Dahinden 2016 as cited in Schinkel 2018). 
In an era in which notions of "crisis" or "security" are constantly linked to migration, there is a crucial need to engage in a critical analysis of legal responses developed in the Global North, in order to develop alternative perspectives. In order to have meaningful complex discussions around immigrant integration, we must re-think how the colonial past has impacted our policy making. The imperialist and neo colonial ideologies shape the formation and continuation of present day immigrant and integration policies in Canada and Germany. Referring to Said's analysis of representation of 'other', the multicultural policy exoticizes and ethnicizes different cultures and therefore 'manages the diversity' by muting and suppressing the social stratification based on race and racial inequalities (Said, 1978; Banerjee and Linstead, 2001). Therefore, Thobani (2007) argues that the discourse of multiculturalism reaffirms the status quo, maintains power relations, and compartmentalizes the race in a simplistic way. The cultural hegemony is reflected in the present and past immigration policies making it clear who has the authoritative voice to define who gets in and who stays at the margins of the society (Krysa et al, 2019).

Abu-Laban emphasizes that it is important to acknowledge that immigration policy in and of itself is inherently exclusionary in nature because "the primary purpose of immigration policy is to deny Canadian citizenship to the majority of the world's inhabitants" ("Keeping 'Em Out" 70). Without this understanding of diversity in Canada, the official multiculturalism and integration policies remains "foundationally anchored in the constitutional order of a monocultural state that upholds a white Eurocentricity as the unmarked norm, a tactitly assumed standard for judging others, and an ideology in deference to a dominant ideology" (Pinder, 2010 as cited in Fleras, 2015, p. 33). In bringing decolonizing discussions to the field of migration 
research, we must first understand how the field has been impacted by colonization, so that we can go about dismantling and reversing those impacts, trends, and trajectories (Coulthard, 2014). The 'integration' policies and practices in Germany and Canada are designed to systemically exclude the 'others'. 'Integration' into an “existing political community may not be desirable or politically acceptable to Indigenous nations who have faced forced family separation through residential schools, loss of land and/or livelihoods, and the systemic social exclusions produced through these state-led practices" (Carfms 2018, n.p). A post colonial analysis of 'integration' in two different contexts highlights how historical, social, structural, and political factors in host countries adversely affect the lives of newcomers. It is essential to develop a counter-hegemonic approach that should be a source of inspiration for emerging scholars researching on the issues of migration, 'integration' and settlement. The insights gleaned from these discussions can enhance the relationships between 'western' communities and newcomers. 


\section{References}

Adib-Moghaddam, A. (2011). A Metahistory of the clash of civilisations: Us and Them beyond orientalism. London, UK: Hurst \& Company.

Ager, A., \& Strang, A. (2008). Understanding Integration: A Conceptual Framework. Journal of Refugee Studies, 21(2), 166-191. doi:10.1093/jrs/fen016

Alba, R., \& Foner, N. (2014). Comparing Immigrant Integration in North America and Western Europe: How Much Do the Grand Narratives Tell Us. International Migration Review, 48 (1), 263-291.

Alba, R. \& Foner, N. (2015). Strangers no more: Immigration and the challenges of integration in North America and Western Europe. Princeton, NJ: Princeton University Press.

Alfred, T. (2010). What is Radical Imagination? Indigenous Struggles in Canada. Affinities: A Journal of Radical Theory, Culture, and Action, 4(2), 5-8.

Alfred, T. (2017). It's all about the land. In McFarlane, P., \& Schabus. N. (Eds.). Whose Land is it Anyway? (pp. 10-14). Vancouver, Canada: Federation of Post-Secondary Educators of BC.

Ashcroft, B., \& Ahluwalia, P. (1999). Edward said: The paradox of identity. London, UK: Routledge

Amir-Mozami, S. (2005). Buried Alive: Multiculturalism in Germany. Institute for the Study of International Migration Review 16, 22-23.

Awgu, I. (2013, April, 1). Why Are Aboriginals Afraid of Integration?. Huffpost. Retrieved from https://www.huffingtonpost.ca/ike-awgu/aboriginal-

integration_b_2411909.html?guce_referrer=aHR0cHM6Ly93d3cuZ29vZ2xlLmNvbS8\&g uce_referrer_sig=AQAAABlWzpLM1VcadfVV6gXn1brX-j4fGPan-

m6zSFzHgA_8dRbFIAvzYJqF6HSu33b0kJ3x_SFo1Vd9Mdp3SCzAB4KhTrV0gH6DN59AE-

forxR08cz4csEzcuzdfDsc3ysOb8FP7G16uqsgkKopBGj6UMQ_747amvoHYHzkVmBlM FY\&guccounter=2

BAMF. (2007). The National Integration Plan: Driver of Integration Policy. Web: 
https://ec.europa.eu/migrantintegration/index.cfm?action=media.download\&uuid=2A91BC 23-E195-CCE2-3F70DDECBCA02D10

BAMF. (2012). National Action Plan on Integration abridged press version. Web: https://www.bundesregierung.de/Content/DE/_Anlagen/IB/2012-01-31-nap-kurzfassungpresseenglisch.pdf?_blob=publicationFile

BAMF. (2016). Integration Act to support and challenge. Web: https://www.bundesregierung.de/Content/EN/Artikel/2016/07_en/2016-05-25integrationsgesetzbeschlossen_en.html

BAMF. (2018). Attendance and Costs. Web: http://www.bamf.de/EN/Willkommen/DeutschLernen/Integrationskurse/TeilnahmeKosten/ teilnahmekosten-node.html68

BAMF. (2018). Local integration projects. Web: http://www.bamf.de/EN/Willkommen/Integrationsprojekte/Engagement/engagementnode.h $\mathrm{tml}$

Bannerji, H. (2000). The dark side of the nation: Essays on multiculturalism, nationalism and gender. Canadian Scholars' Press.

Banerjee, S.B., and Linstead, S. (2001). Globalization, multiculturalism and other fictions: colonialism for the new millennium? Organization, 8(4), 683-722.

Banerjee, S.B. and Prasad, A. (2008).Guest editorial: introduction to the special issue on 'critical reflections on management and organizations: a postcolonial perspective. Critical Perspectives on International Business, 4(2), 90-98.

Banting, K. and Kymlicka, W. (2010).Canadian multiculturalism: global anxieties and local debates. British Journal of Canadian Studies, 23(1), 43-72. 
Battiste, M. (2013). Decolonizing education: Nourishing the learning spirit. Saskatoon, Canada: Purich Publishing.

Bauder, H. (ed.) (2019). Putting family first: Migration and integration in Canada. Vancouver, Canada: University of British Columbia Press.

Bauder, H. (2011). Closing the Immigration-Aboriginal Parallax Gap. Geoforum 42, 517-519.

Bauder, H. (2008). Media discourse and the new German Immigration Law. Journal of Ethnic and Migration Studies , 34 (1), 95-112.

Bauder, H. (2011). Immigration dialectic: Imagining community, economy, and nation. Toronto, Canada: University of Toronto Press.

Bauder, H. (2008). Neoliberalism and the economic utility of immigration: Media perspectives of Germany's Immigration Law. Antipode, 40 (1), 55-78.

Bauder, H., \& Jayaraman, R. (2014). Immigrant workers in the immigrant service sector: segmentation and career mobility in Canada and Germany. Transnational Social Review, 4(2/3), 176-192.

Bauder, H., Lenard, P.T., \& Straehle C. (2014). Lessons from Canada and Germany: Immigration and integration experiences compared. Comparative Migration Studies 2(1), $1-7$.

Barker, A. J. (2012). Locating settler Colonialism. Journal of Colonialism and Colonial History 13(3), 66.

Biles, J. (2008). Integration policies in English-speaking Canada. In Biles, J., Burstein, M., \& Frideres, J. (eds.). Immigration and Integration in Canada in the Twenty-first Century. Kingston, Canada: Queen's University, School of Policy Studies.

Bonita, L. \& Dua, E. (2005). Decolonizing Antiracism. Social Justice, 32(2) 120-143.

Boersma, S., \& Schinkel, W. (2018). Imaginaries of postponed arrival: On seeing 'society' and its 'immigrants'. Cultural Studies, 32(2). doi:10.1080/09502386.2017.1354047. 
Brown, L. A., and Strega, S. (2005). Research as Resistance: Critical, Indigenous and Antioppressive Approaches. Toronto, Canada: Canadian Scholars' Press.

Campbell, K. (2004) . B.C. First Nations Studies Teacher's Guide. B.C. Ministry of Education.

Campbell, L. (2012). Multikulti Ist Doch 'Ne Erfolgreiche Realität: Why Tolerance is Vital for German Economic Growth. Boston College International and Comparative Law Review, 35 (2), 449-480.

Carter, S. (1996). Categories and Terrains of Exclusion: Constructing the 'Indian Woman' in the Early Settlement Era in Western Canada. In Parr, J. \& Rosenfeld, M. (Eds.), Gender and History in Canada (pp. 30-49). Toronto: Copp Clark.

CARFMS/ACERMF (2018, October). Interrogating Integration. Retrieved from http://carfms.org/carfms-2019-call-for-papers/

CBC. (2012, March 16). Canadians' duty to remember Shafia girls, PM says. CBC News. Retrieved from https://www.cbc.ca/news/canada/montreal/canadians-duty-to-remembershafia-girls-pm-says-1.1286324

Chatterjee, S. (2018). Immigration, anti-Racism, and Indigenous self-determination: Towards a comprehensive analysis of contemporary settler colonial. Social Identities:Journal for the Study of Race, Nation and Culture, 25(5), 644-661. doi:10.1080/13504630.2018.1473154

Chatterjee, S. (2015). Skills to build the Nation: The ideology of 'Canadian experience and nationalism in global knowledge regime. Ethnicities, 15(4): 544-567.

Coleman, D. (2015). Indigenous place and diaspora space: Of literalism and abstraction. Settler Colonial Studies, 6(1), 61-76. doi:10.1080/2201473X.2014.1000913

Coulthard, G. S. (2014) Red skin, white masks: Rejecting the Colonial politics of recognition. 
Minneapolis, MN: University of Minnesota.

Coulthard, G. (2017). Going international to decolonize. In McFarlane, P., \& Schabus. N. (Eds.). Whose Land is it Anyway? (pp. 57-61). Vancouver, Canada: Federation of Post-Secondary Educators of BC.

Dhamoon, R. (2010). Identity/difference Politics. Vancouver, Canada: University of British Columbia Press.

Dua, E. (2000). The Hindu Women's Question: Canadian Nation Building and the Social Construction of Gender for South Asian-Canadian Women. In Calliste, A. \& Sefa Dei, G. J. (Eds.) Anti-Racist Feminism: Critical Race and Gender Studies. (pp. 55-72). Halifax: Fernwood.

Fleras, A. (2015). Multicultural Media in a Post-Multicultural Canada? Rethinking Integration. Global Media Journal: Canadian Edition, 8(2), 25-47.

Focus Migration (2008). Integration policy at a regional level in Germany. (Policy Brief 10). Hamburg: Hamburg Institute of International Economics. Web: www.bpb.de/system/files/pdf/HEJLVH.pdf

Foucault, M. (1981), “The order of discourse”, in Young, R. (Ed.), Untying the Text: A PostStructuralist Reader, Routledge and Kegan Paul, Boston, 48-78.

Foucault, M. (1982), “The subject and power”, Critical Inquiry, 8(4), 777-795.

Foucault, M. (2001), "Truth and power", in Lynch, M. P. (Ed.), The Nature of Truth: Classic and Contemporary Perspectives, MIT Press, Cambridge, pp. 317-319.

Friedrichsmeyer, S., Lennox, S., and Zantop, S. (1998). The imperialist imagination: German colonialism and its legacy. Ann Arbor, MI: University of Michigan Press. 
Frideres, J. (2008). Creating an inclusive society: Promoting social integration in Canada. In Biles, J.,Burstein, M., \& Aiken, T. (eds.). Immigration and Integration in Canada in the Twenty-first Century (pp. 77-102). Kingston, Canada: Queen's University, School of Policy Studies.

Galabuzi, G.-E. (2006), Canada's economic apartheid: The social exclusion of racialized groups in the New Century. Toronto, Canada: Canadian Scholars' Press.

Goodman, S. W. (2010). Integration requirements for integration's sake? Identifying, categorising and comparing civic integration policies. Journal of Ethnic and Migration Studies, 36(5), 753-772. doi: 10.1080/13691831003764300

Government of Canada (2013), "Snapshot of racialized poverty in Canada", available at: www.canada.ca/ en/employment-socialdevelopment/programs/communities/reports/poverty-profile-snapshot.html (accessed 9 September 2018).

Government of Canada (2015), "Canadian multiculturalism act", available at: http://lawslois.justice.gc.ca/eng/acts/C-18.7/page-1.html (accessed 9 September 2018).

Green, S. (2005) Immigration and integration policy: Between incrementalism and nondecisions. In Green, S., \& Paterson, W. E. (eds). Governance in Contemporary Germany: The Semi-sovereign State Revisited. Cambridge, UK: Cambridge University Press.

Halm, D. (2017). Access to Religious and Ethno-cultural Communities in Germany. in Structural Context of Refugee Integration in Canada and Germany eds. Annette Korntheuer, Paul Pritchard and Debora B. Maehler. Liebniz: Leibniz Institute for the Social Sciences, 107113.

Hanselmann, C. (2001). Urban Aboriginal people in Western Canada. Canada West Foundation. Retrieved from https://cwf.ca/wp- 
content/uploads/2015/12/CWF_UrbanAboriginalPeopleWesternCanada_Report_SEP2001. pdf

Hiebert, D. (2016). What's so special about Canada? Understanding the resilience of immigration and multiculturalism. Migration Policy Institute. Retrieved from https://www.migrationpolicy.org/research/whats-so-special-about-canada-understandingresilience-immigration-and-multiculturalism

Hiebert, D. \& Sherrell, K. (2009). The Integration and Inclusion of Newcomers in British Columbia.Working Paper No. 2009-11, Vancouver: Metropolis British Columbia.

Kakel III, C. (2011). The American west and the Nazi east. Basingstoke, UK: Palgrave Macmillan.

Kay. J. (2013, May, 8). Urban-bound aboriginals pose Canada's biggest integration challenge, not immigrants. National Post. Retrieved from https://nationalpost.com/opinion/jonathankay-aboriginals-pose-canadas-biggest-assimilation-challenge-not-immigrants

Kastoryano, R. (2018). Multiculturalism and interculturalism: redefining nationhood and solidarity. Comparative Migration Studies, 6(17), 1-11. doi:10.1186/s40878-018-0082-6

Khan, S., Allan, R., Pennington, J., \& Richardson, L. (2015). Paying our dues: The importance of newcomer solidarity with the Indigenous movement for self-determination in Canada. Canadian Journal of Native Studies, 35(1), 145.

Knowles, V. (2016). Strangers at Our Gates: Canadian Immigration and Immigration Policy 1540-2015. Toronto, Canada: Dundurn Press.

Kortmann, M. (2018). Debating the 'integration of Islam': the discourse between Governmental actors and Islamic representatives in Germany and the Netherlands. Comparative Migration Studies, 6(24), 1-20. doi:10.1186/s40878-018-0086-2 
Krysa, I., Paludi, M. and Mills, A. (2019), "The racialization of immigrants in Canada - a historical investigation how race still matters", Journal of Management History, 25(1), 97-113. https://doi-org.ezproxy.lib.ryerson.ca/10.1108/JMH-09-2018-0048

Kühne, T. (2013). Colonialism and the holocaust: continuities, causations, and complexities. Journal of Genocide Research, 15(3), 339-362. doi:10.1080/14623528.2013.82122

Kymlicka, W. (2010). The current state of multiculturalism in Canada and research themes on Canadian multiculturalism 2008-2010. Retrieved from http://www.cic.gc.ca/english/pdf/pub/multi-state.pdf

Lawrence, B. and Dua, E. (2005) .Decolonizing Antiracism. Social Justice 32(4):120-143.

Levitt, P., \& Schiller, N. G. (2004). Conceptualizing simultaneity: A transnational social field perspective on society. International Migration Review, 38(3), 1002-1039. doi:10.1111/j.1747-7379.2004.tb00227.x

Locke, T. (2004). Critical Discourse Analysis. New York, NY: Continuum International Publishing Group.

MacDonald, D. (2014) Aboriginal Peoples and Multicultural Reform in Canada: Prospects for a New Binational Society. Canadian Journal of Sociology 39(1), 65-86.

Mama, A. (1997). Sheroes and villains: Conceptualizing colonial and contemporary violence against women in Africa. Alexander, M,. Mohanty, C. (Eds.). NY: Routledge

Manuel, A. (2017). From dispossession to dependency. In McFarlane, P., \& Schabus. N. (Eds.). Whose Land is it Anyway? (pp. 18-21). Vancouver, Canada: Federation of Post-Secondary Educators of BC.

McFarlane, P., and Schabus, N. (Eds.). (2017). Whose land is it anyway?. Vancouver, Canada: 
Federation of Post-Secondary Educators of BC. Retrieved from https://fpse.ca/sites/default/files/news_files/Decolonization\%20Handbook.pdf

Narayan, U. (2000). Undoing the "Package picture" of culture Signs. Journal of women, Culture and Society, 25(4)1083-1086.

Neuman, L.W (2006). Social Research Methods: Qualitative and Quantitative Approaches. Boston, MA: Pearson Education.

Ontario Human Rights Commission, (2018), Racial discrimination, race and racism, available at: www.ohrc.on.ca/en/racial-discrimination-race-and-racism-fact-sheet

Ore. J. (2018, February, 12). 'You don't belong here': Integrating Indigenous 'cultural humility' into health care. $C b c$. Retrieved from https://www.cbc.ca/radio/thecurrent/features/facingrace/you-don-t-belong-here-integrating-indigenous-cultural-humility-into-health-care1.4520698

Osterhammel, J. (1997). Colonialism: A theoretical overview. Princeton, N.J :MarkusWiener Publishers.

Palmater, P. (2017). Decolonization is taking back our power. In McFarlane, P., \& Schabus. N. (Eds.). Whose Land is it Anyway? (pp. 73-78). Vancouver, Canada: Federation of PostSecondary Educators of BC.

Porter, J. (1965). The vertical mosaic: An analysis of social class and power in Canada. Toronto, Canada: University of Toronto Press.

Prem, M. (2017). Access to resettlement services in Germany: Language options for refugees and asylum-seekers in Germany. In Korntheuer, A., Pritchard, P., \& Maehler, D. B. (Eds.). Structural Context of Refugee Integration in Canada and Germany. Liebniz: Leibniz Institute for the Social Sciences, 119-127.

Red Thread (2018, December). Democracy not integration. Retrieved from http://redthread.org/en/democracy-not-integration/ 
Reitz, J.G. (2011), "Taxi driver syndrome: behind the scenes immigration changes are creating new problems on top of old ones", Literary Review Canada, available at: http://reviewcanada.ca/magazine/2011/03/taxi-driver-syndrome/(accessed 9 September 2018).

Robertson, G. (2012, August 17). Bank of Canada slammed over 'racist' move to scrap asian image from $\$ 100$ bills. The Globe and Mail Retrieved from www.theglobeandmail.com/news/national/bank-of-canada-slammed-over-racist-move-toscrap-asian-image-from-100-bills/article4485307/

Robinson, V. (1998). Defining and measuring successful refugee integration. Antwerp, Brussels: ECRE

Rogan, M. (2008, December). Girl Interrupted. Toronto Life, 42(12), 52.

Richmond, T. \& Shields, J. (2005). NGO-Government Relations and Immigrant Services: Contradictions and Challenges. Journal of International Migration and Integration 6 (3/4), 513-526.

Robertson, G. (2012, August 17), "Bank of Canada slammed over 'racist' move to scrap asian image from $\$ 100$ bills", The Globe and Mail, available at: www.theglobeandmail.com/news/national/bank-of-canada-slammed-over-racistmove-to-scrap-asian-image-from-100-bills/article4485307/ (accessed 9 September 2018).

Roberts, B. (1979). A work of empire: Canadian reformers and British female immigration (pp. 185-201; 231-233). In Kealey, L. (Ed.) (1979). A Not Unreasonable Claim: Women and Reform in Canada, 1880s-1920s. Toronto, Canada: The Women's Press.

Rogan, M. (2008, December). “Girl Interrupted”. Toronto Life, 42(12), 52.

Russell, C. (2005). An overview of the integrative research review. Progress in Transplantation 68 
$15(1), 8-13$.

Saharso, S. (2019). Who needs integration? Debating a central, yet increasingly contested concept in migration studies. Comparative Migration Studies 7(16). doi:10.1186/s40878019-0123-9

Said, E.W. (1978), Orientalism, Pantheon Books, New York, NY.

Schmidke, O. (2014). "Beyond National Models? Governing Migration and Integration at the regional and local levels in Canada and Germany" Comparative Migration Studies. 2(1), 77-99.

Schinkel, W. (2013). The imagination of 'society' in measurements of immigrant integration. Ethnic and Racial Studies, 36(7), 1142-1161.

Schinkel, W. (2017). Imagined societies. A critique of immigrant integration in Western Europe. Cambridge, UK: Cambridge University Press.

Schinkel, W. (2018). Against 'immigrant integration': for an end to neocolonial knowledge production. Comparative migration studies, 6(1), 31. doi:10.1186/s40878-018-0095-1

Schneider, P. (2005, December, 4). The new Berlin Wall. The New York Times Magazine. Retrieved from https://www.nytimes.com/2005/12/04/magazine/the-new-berlin-wall.html

Sharma, N. and Wright, C. (2008-09). Decolonizing Resistance, Challenging Colonial States. Social Justice, 35(3): 120-138.

Shields, J., Turegun, A., and Lowe, S. (2014). Final Report: Settlement and Integration Research Synthesis. Toronto: Toronto: Centre of Excellence for Research on Immigration and Settlement. Retrieved from http://ceris.ca/wp- content/uploads/2015/01/CERIS-ResearchSynthesis-on-Settlementand-Integration.pdfl 
Simpson, A. (2014) Mohawk Interruptus: Political Life Across the Borders of Settler States. Race and Racialization. Canadian Scholars' Press.

Srikanth, H. (2012). Multiculturalism and the Aboriginal Peoples in Canada. Economic and Political Weekly, 47(23), 17-21. Retrieved from http://www.jstor.org/stable/23214913

St. Denis, V. (2011). Silencing Aboriginal curricular content and perspectives through multiculturalism: "There are other children here". Review of education, pedagogy, and cultural studies, 33(4), 306-317.

Stanley, A., Arat-Koç, S., Bertram, L. K. and King, H. (2014) Addressing the IndigenousImmigration "Parallax Gap." Antipode Foundation. Retreived from : https://antipodeonline.org/2014/06/18/addressing-the-indigenous-immigration-parallaxgap/

Stehle, M. (2006). Narrating the Ghetto, Narrating Europe: From Berlin, Kreuzberg to the Banlieues of Paris. Westminster Papers in Communication and Culture, 3(3), 48-70.

Süssmuth, R. (2009). The Future of Migration and Integration Policy in Germany. Washington, DC:Migration Policy Institute. Web: https://www.migrationpolicy.org/pubs/TCMGermanPolicy.pdf

Thobani, S. (2000), Closing ranks: Racism and Sexism in Canada's Immigration Policy. Race and Class, 42(1), 35-54.

Thobani, S. (2007), Exalted Subjects: Studies in the Making of Race and Nation in Canada, University of Toronto Press, Toronto.

Truth and Reconciliation Commission of Canada (2015) Honouring the Truth, Reconciling for the Future: Summary of the Final Report of the Truth and Reconciliation Commission of Canada, esp, 312-315. 
Trudeau, D., and Veronis, L. (2009). Enacting state restructuring: NGOs as 'translation mechanisms.'Environment and Planning D,Society and Space, 27, 1117-1134.

Trudeau, J. (2015). Minister of Immigration, Refugees and Citizenship Mandate Letter. Office of the Prime Minister. Ottawa, Canada. Retrieved from https://pm.gc.ca/en/mandateletters/minister-immigration-refugees-and-citizenship-mandate-letter

Tuck, E., Rowe, A. (2017). Settler Colonialism and Cultural Studies: Ongoing Settlement, Cultural Production, and Resistance. Cultural Studies 17(1), 3-13.

Upadhyay, N. (2013). Pernicious continuities, Un/settling violence, race and colonialism. Sikh Formations 9(4), 263-268.

Valiante, G. (2016, September, 15). Canadians cannot be overly impatient with integration of immigrants, Justin Trudeau says. $C B C$. Retrieved from https://www.cbc.ca/news/canada/montreal/trudeau-compares-muslim-discrimination-toitalians-and-greeks-1.3763477

Walia, H. (2012). Decolonizing together. Briarpatch. https://briarpatchmagazine.com/articles/view/decolonizing-together

Walia, H. (2013). Undoing Border Imperialism. Oakland, CA: AK Press

Wood, K. P. and Gilbert, L. (2005). Multiculturalism in Canada: Accidental Discourse, Alternative Vision, Urban Practice. International Journal of Urban and Regional Research, 29, 679-691.

Zapata-Barrero, R. (2017). Interculturalism in the post-multicultural debate: a defence. Comparative Migration Studies, 5. 